\title{
EchoGéo
}

$47 \mid 2019$

Nouvelles géographies de la collecte

\section{Picturing Waste}

Materials, bodies and practices

Claudia Cirelli, Bénédicte Florin and Rémi de Bercegol

\section{(2) OpenEdition}

Journals

Electronic version

URL: https://journals.openedition.org/echogeo/18549

DOI: 10.4000/echogeo.18549

ISSN: 1963-1197

Publisher

Pôle de recherche pour l'organisation et la diffusion de l'information géographique (CNRS UMR 8586)

Electronic reference

Claudia Cirelli, Bénédicte Florin and Rémi de Bercegol, "Picturing Waste", EchoGéo [Online], 47 | 2019,

Online since 09 March 2020, connection on 10 August 2021. URL: http://journals.openedition.org/

echogeo/18549 ; DOI: https://doi.org/10.4000/echogeo.18549

This text was automatically generated on 10 August 2021

EchoGéo est mis à disposition selon les termes de la licence Creative Commons Attribution - Pas d'Utilisation Commerciale - Pas de Modification 4.0 International (CC BY-NC-ND) 


\title{
Picturing Waste
}

\author{
Materials, bodies and practices \\ Claudia Cirelli, Bénédicte Florin and Rémi de Bercegol
}

\section{Photographs and captions:}

Rémi de Bercegol, CNRS Research Fellow and member of the PRODIG Research Unit.

Jérémy Cavé, consultant in urban ecology, Lecturer at IEP (Institute of Political Studies)

Claudia Cirelli, Associate Researcher for the CITERES Research Unit

Bénédicte Florin, Senior Lecturer at Université de Tours, member of the CITERES Research Unit

Pascal Garret, architect, sociologist and freelance photographer

Mikaëla Le Meur, doctoral student at Université Libre de Bruxelles

Adeline Pierrat, Senior Lecturer in Geography at Université du Mans, member of the ESO

Research Unit

Mélanie Rateau, doctoral student, LATTS Laboratory (Université Gustave Eiffel)

Rémi Reboux, graduate from EHESS Marseille and Sciences Po Paris.

\section{Introduction}

1 The individuals who work with waste are often identified with the materials they handle and regarded as marginals. By reclaiming and recycling waste, these workers salvage valuable materials from destruction, and yet they are stigmatized and perceived as contaminated (Lhuilier and Cochin 1999). This paradox is illustrated, sometimes involuntarily, by the many images that represent men and women working in degrading conditions, against landscapes straight out of Dante's Inferno: iconic images that capture and exemplify human misery.

2 The photographs in this portfolio show the universe of "waste workers" in a different light (Corteel and Le Ray 2011). Presented in a travelling exhibition (entitled in french "La Mise en Image du Rebut: Matières, Corp(us) et Pratiques Autour des Déchets"1), these photographs are the product of a reflection on the status of images in research addressing the issue of waste. This work has been conducted as part of the "Sociétés Urbaines et Déchets" project ("Urban Societies and Waste" - SUD²): a network that combines diverse approaches and field studies to analyze the social, cultural, political, 
economic and spatial processes deployed around waste management, thus affecting the workers portrayed here. In 2016, the construction of this photographic corpus was discussed during a cross-disciplinary seminar-workshop involving members of the SUD network and external researchers with an interest in image (photography and anthropology, ethnographic film, curators). Topics addressed included the place of images in academic research, the power and values assigned to these images and their social reception. In line with Daniel Friedmann (2010) who recommends analyzing the socio-filmic effects of film, we questioned the socio-photographic effects of imagemaking, beyond the actual contents pictured in these images. How do images capture and translate the social mutations affecting waste? What does this form of "social image-making" (Gunthert 2007) express and reveal concerning evolutions of the place of waste workers in urban societies? Other issues included the question of the "nobility of the abject" (Dagognet 2009) and the "aesthetics of chaos" (Jeanjean 2006): is the sole function of photographs to complement, or even simply to "embellish" (Sontag 1977) a written argument? Or should they be seen as a material, tool or language in its own right which, by giving visibility to these marginalized workers, can "reveal certain aspects of reality that remain hidden in the flow of everyday life" (Louvereau de la Guigneraye and Arlaud, 2007, 104)?

3 These questions, and many more, informed the contents of the exhibition, which was gradually augmented with new images. These images were selected according to a number of criteria (dignity, privacy protection, consent of the subject), sociologically contextualized by a systematic interview (conducted by the researcher with the subject(s) of the photograph), and complemented by technical information (camera, place, date) $)^{3}$.

4 Far from conveying an image of poverty and marginality, these portraits of waste reclaimers place the spotlight on men and women, stripping them from the stigma associated with being waste. These are normal workers captured in the completion of routine tasks: workers who want to be regarded as equals and who want their work to be recognized by society. These people increasingly claim their social rights and the legitimization of their contribution to recycling, waste management and environmental protection. The researcher/photographer asked each subject to choose their own pose. Their postures, smiles and gazes into the lens reflect their aspiration to present themselves and their job as ordinary. Through the mise-en-scène, these workers want to contribute to a better recognition and rehabilitation of their work and image.

5 This portfolio presents a concise selection taken from the corpus of the exhibition. It is displayed in three parts, reflecting the three phases of the reclaiming of waste: the collection of waste in cities or landfill sites; the sorting, dismantling and cleaning of materials in the waste pickers' districts, in depots or cooperative warehouses; and finally, the transformation and marketing of materials.

\section{Collection}

The section on waste collection in the city documents the waste pickers' practices (at day and at night), the inventiveness of their tools and vehicles, their routes, as well as their comprehensive knowledge of urban spaces: the portraits below show that the workers know where and when they will find the most valuable resources in each 
neighborhood, street and even building. This know-how is deployed in public spaces where they are particularly visible and often vulnerable, which forces them to "negotiate" their presence with residents, authorities and drivers.

7 The collection is also conducted in landfill sites, which in some case are also where the waste pickers live. On these sites, the methane generated by fermentation can form pockets of highly flammable and explosive gases, threatening to collapse over the workers and cause fires. Landslides or collapses of heaps of detritus are frequent - for instance, deathly accidents occurred in a landfill site in Addis-Abeba in March 2017, and in Ghazipur near Delhi in September of the same year. The "juice" leaked from waste, also called lixivium, is loaded with organic and chemical pollutants and heavy metals. These hazards are combined with a higher incidence of health risks, diseases and wounds than anywhere else (Chokhandre et al. 2017).

8 In areas where these work places are also living places, the proximity with waste materials also affects the waste pickers' environment: accumulation of residue awaiting to be processed; irrecoverable materials that are in some cases never evacuated but burnt by the waste pickers themselves to get rid of them or extract materials such as copper; air, soil, waterways and superficial groundwater pollution...

9 As shown by these images, another "informal reclaiming" method is used by city employees in charge of waste collection, for instance in Mexico City or Lima. This method involves selecting and sorting more valuable materials before they reach the dump (or the dhalao - or collection point - in Delhi).

Without ignoring the specific contexts associated with the universe of waste, or understating the risks taken by those who deal with these materials, these portraits, complemented by interviews with researchers, show the work conducted by these men and women as an essential link in the waste collection chain, and more globally in a system that could not function without them. 


\section{Illustration 1 - Hooks and baskets: the waste pickers' tools}

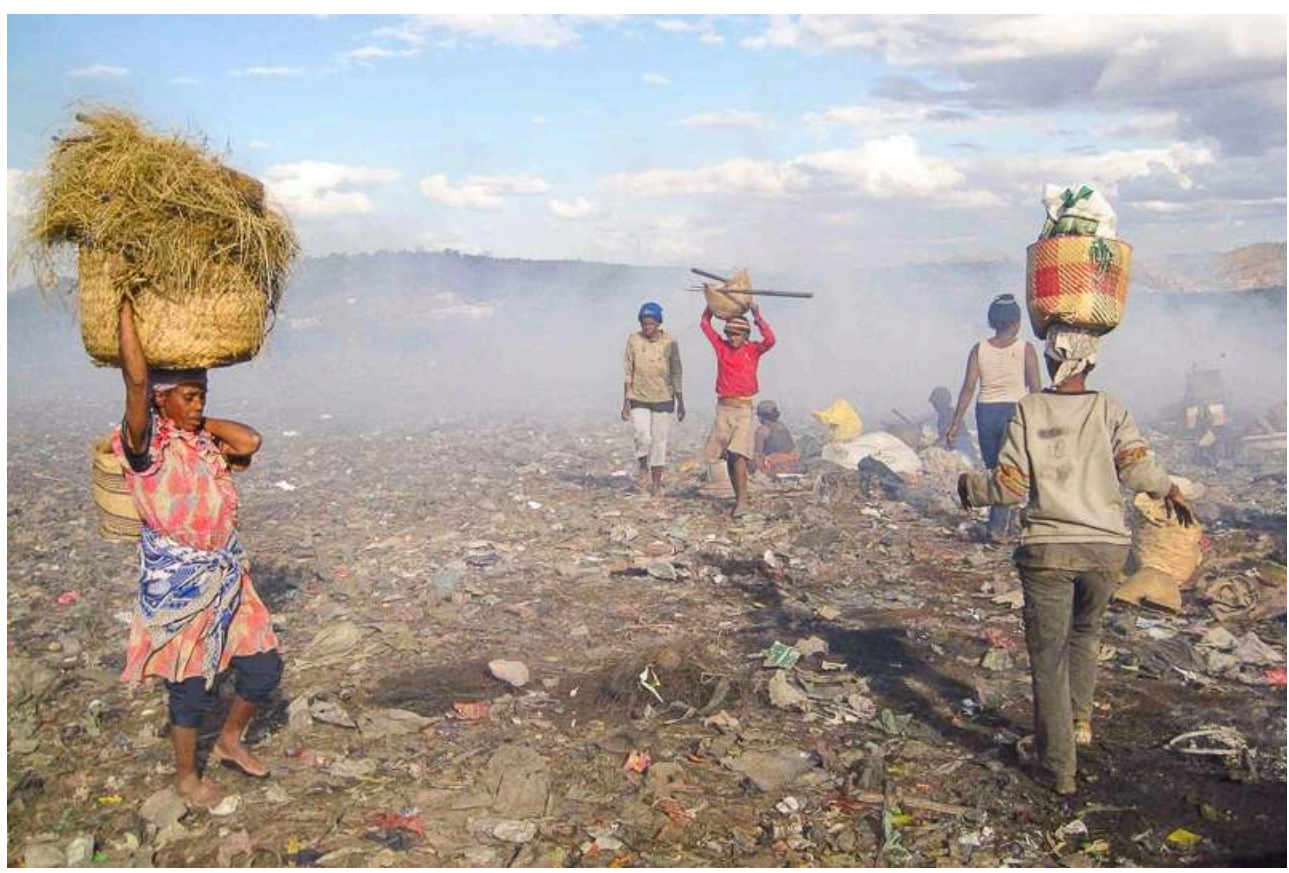

This photograph shows the slow progress of waste pickers around the Andralanitra landfill site as they finish their round in the mid-morning. These workers, referred to as "chiffonniers" (ragpickers) in Madagascar, rummage the mountains of garbage for their most valuable objects. The baskets and hooks that are visible here are the only tools at their disposal. The waste pickers are the first link in a complex network of intermediaries. The materials and objects are then sold on to wholesalers and redirected to specialized markets in the city centre or to craftsmen's workshops. The waste pickers of Andralanitra are showing no hostility towards the photographer: they are used to the media coverage received by Father Pedro's charity, founded in 1989, which supports the most vulnerable.

Antananarivo, Madagascar, June 2015. Photo by A. Pierrat. 


\section{Illustration 2 - The power of garbage}

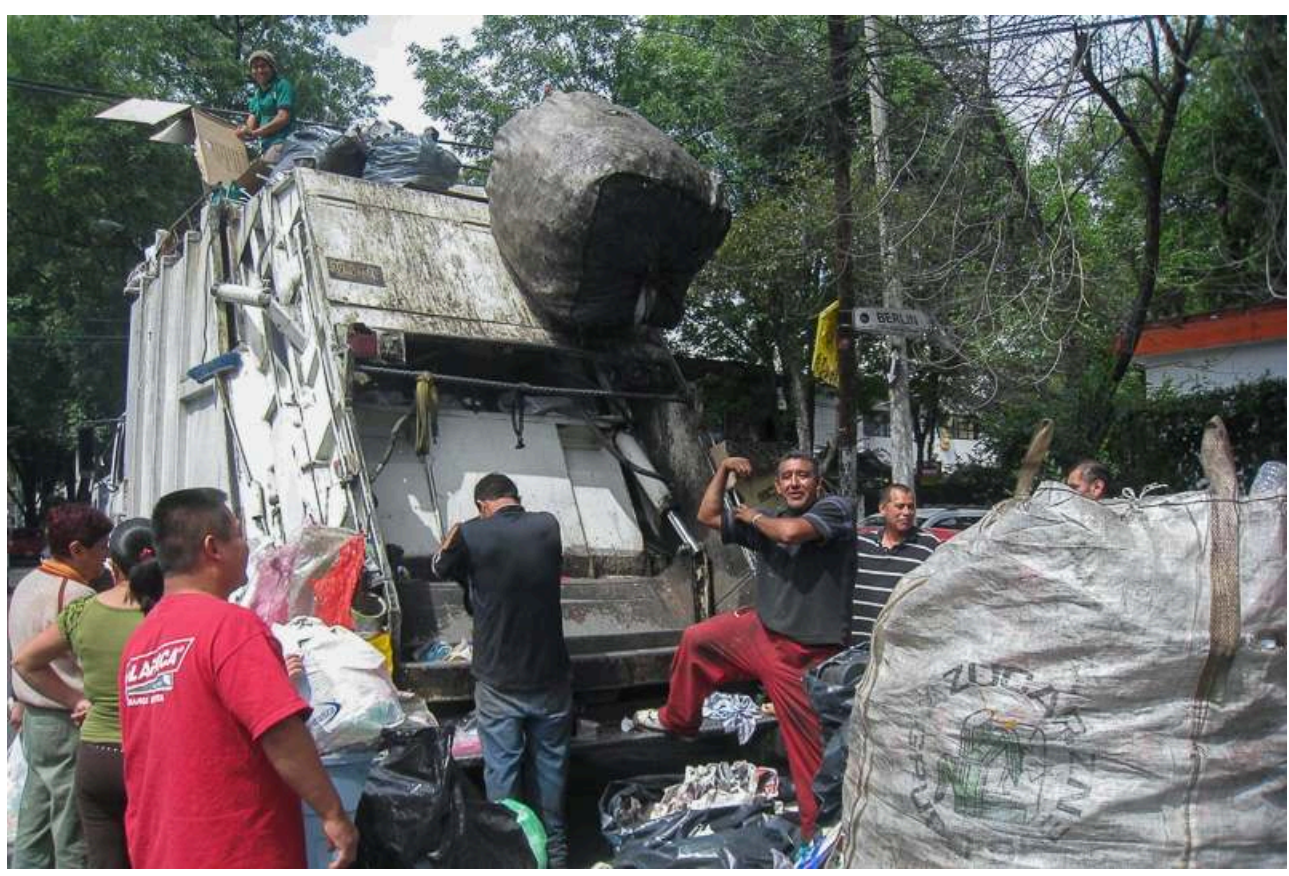

The worker at the centre of this image is one of 10,000 "volunteers" who pick up waste in the Mexican capital. These people make a living from tips given by residents and from the sale of reclaimed materials. In Mexico City, the waste collection system is managed both by the City Council and by waste pickers, or pepenadores. When asked whether we could take his photo the man showed off his muscles, thus emphasizing the manliness of his job. His posture is a show of power: the power required to lift heavy weights, but also to endure the dangers associated with the handling of dirty materials. The huge black bag filled with cans he hauls above his head symbolizes the hazards of this profession.

Mexico D.F., Mexico, March 2012. Photo by C. Cirelli. 
Illustration 3 - Dona Graça e o seu carrinho/ Dona Graça and her cart

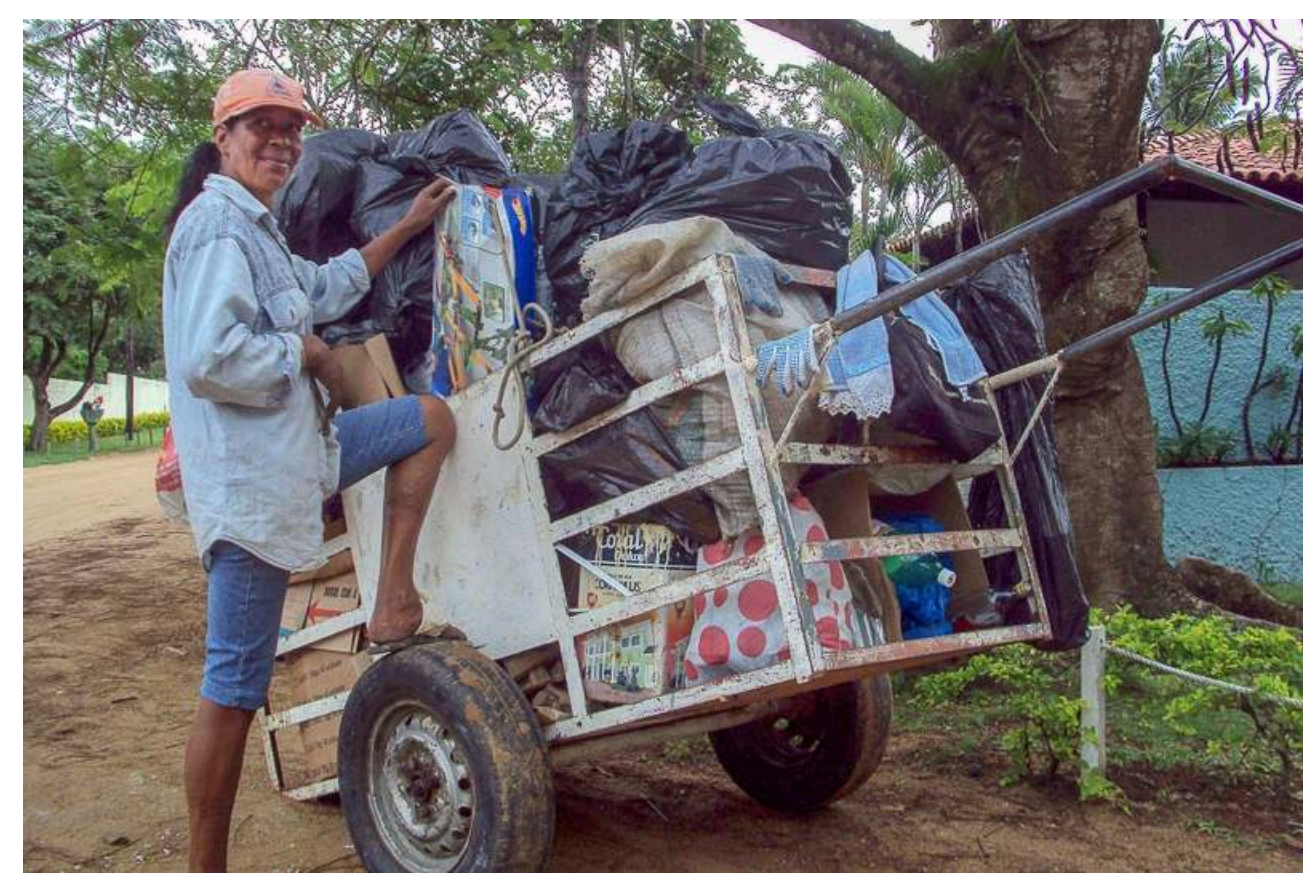

Dona Graça, who has never worked in the formal sector, introduces herself as a recicladora (recycler). She takes pride in her white cart, which is a symbol for her independence. Dona Graça, who has been reclaiming waste in this neighbourhood for years, explains that "people throw some things away on purpose, especially for [her]". While these reclaimed items are the most lucrative for her, she also has to pick up other, less interesting objects. But she is fine with that: her recovery work is made considerably easier by the fact that the residents have already sorted their own waste and placed packaging into a separate bag. This makes her work much faster and also much less off-putting, as the materials she handles are clean. Her work no longer feels clandestine: she has the tangible impression of engaging in a respectful interaction.

Vitória, Espírito Santo, Brasil, July 2010. Photo by J. Cavé. 
Illustration 4 - Finding dignity in garbage

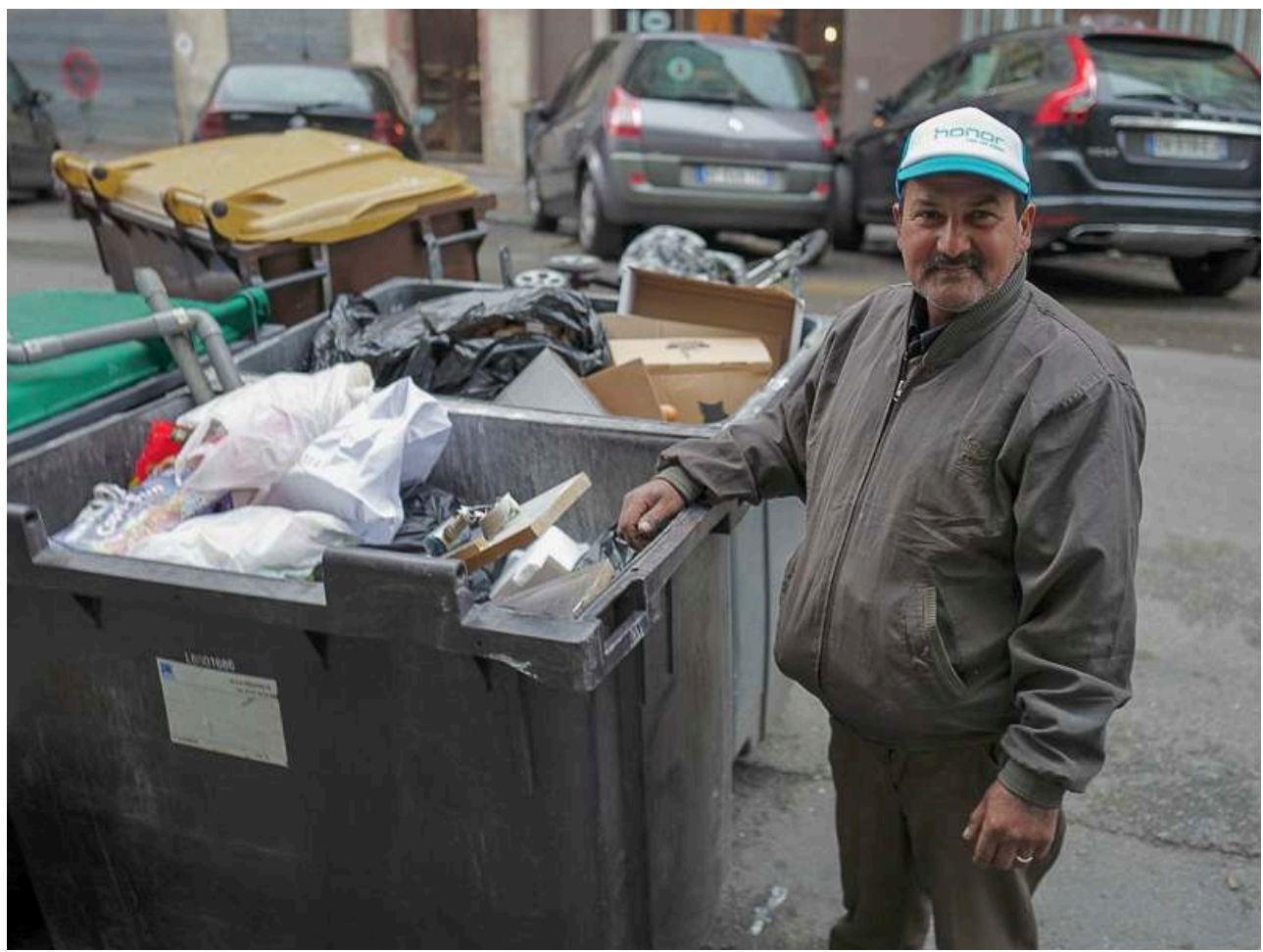

I met this man in Marseille on a cold February morning. A Roma from Romania, he came to France to escape poverty and is now living with his family in a squat in the neighbourhood of Le Panier. As he was unable to find a job, he makes a living rummaging through waste containers in search of old electric wires, from which he extracts copper that he sells by weight. The man chose his own pose for the portrait. The photograph reconciles the irreconcilable by showing the dignity of a man who rummages through garbage ${ }^{4}$.

Marseille, France, February 2016. Photo by P. Garret. 


\section{Illustration 5 - The story of Yunus}

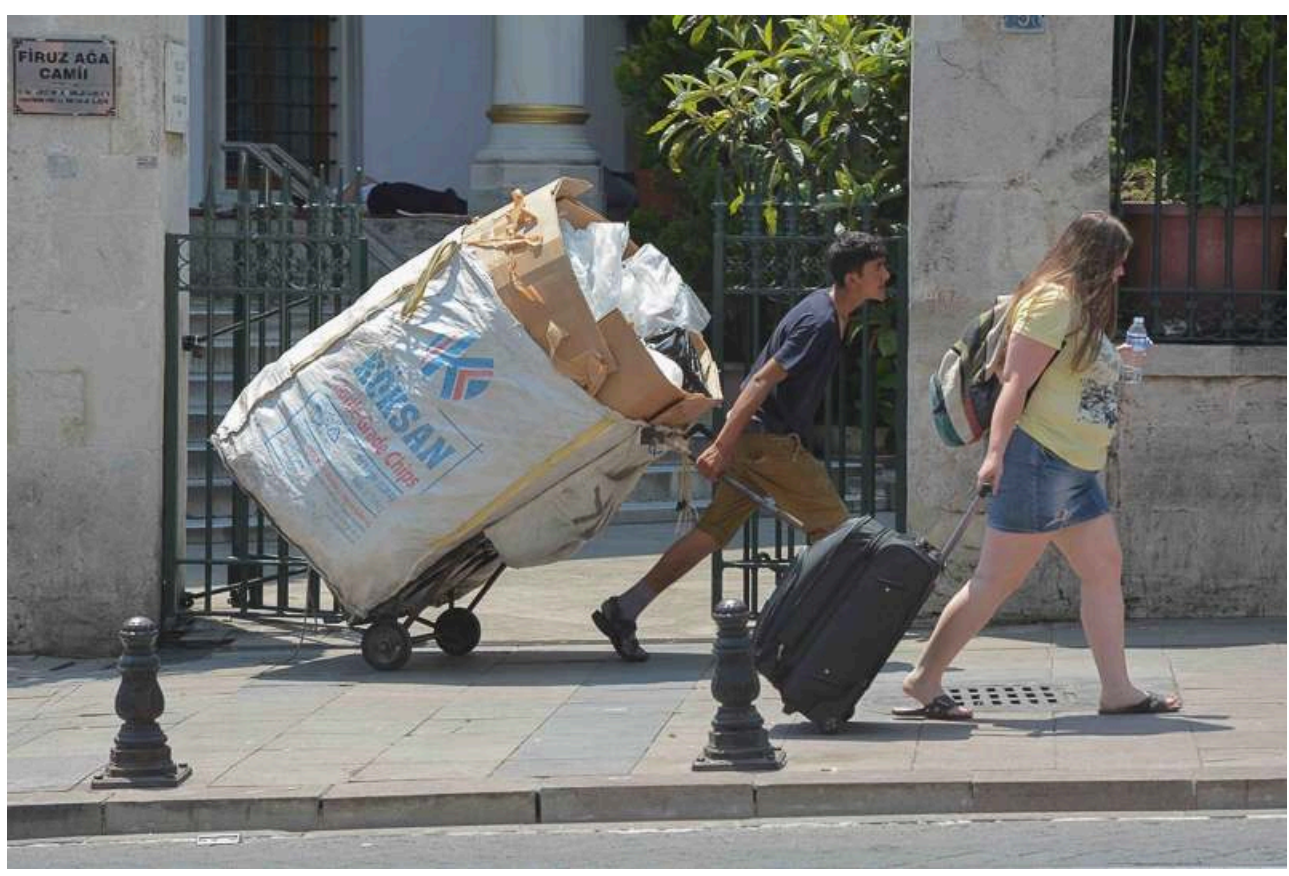

Yunus, a young Turkish waste picker, is on his way back from a round of the streets of Istanbul. He was photographed in the tourist district of Sultan Ahmet. The photograph highlights the striking contrast between two parallel worlds: on the one side Yunus walking in long strides, hauling his heavy burden of waste; on the other a tourist in flipflops, leisurely dragging her wheeled suitcase. Each of Yunus' tours lasts for about two hours and covers a distance of almost ten kilometres. He does on average four or five of these per day, six days a week. Aged 16, he's part of a group of a dozen young waste pickers who settled together in a patch of urban wasteland in the Suleymaniye neighbourhood. All natives of the region of Aksaray (about $700 \mathrm{~km}$ from Istanbul), the group collectively bought a truck and organized themselves as a cooperative with no chief above them.

Istanbul, Turkey, July 2015. Photo by P. Garret/MuCEM, fieldwork in collaboration with B. Florin. 
Illustration 6 - Lunch break

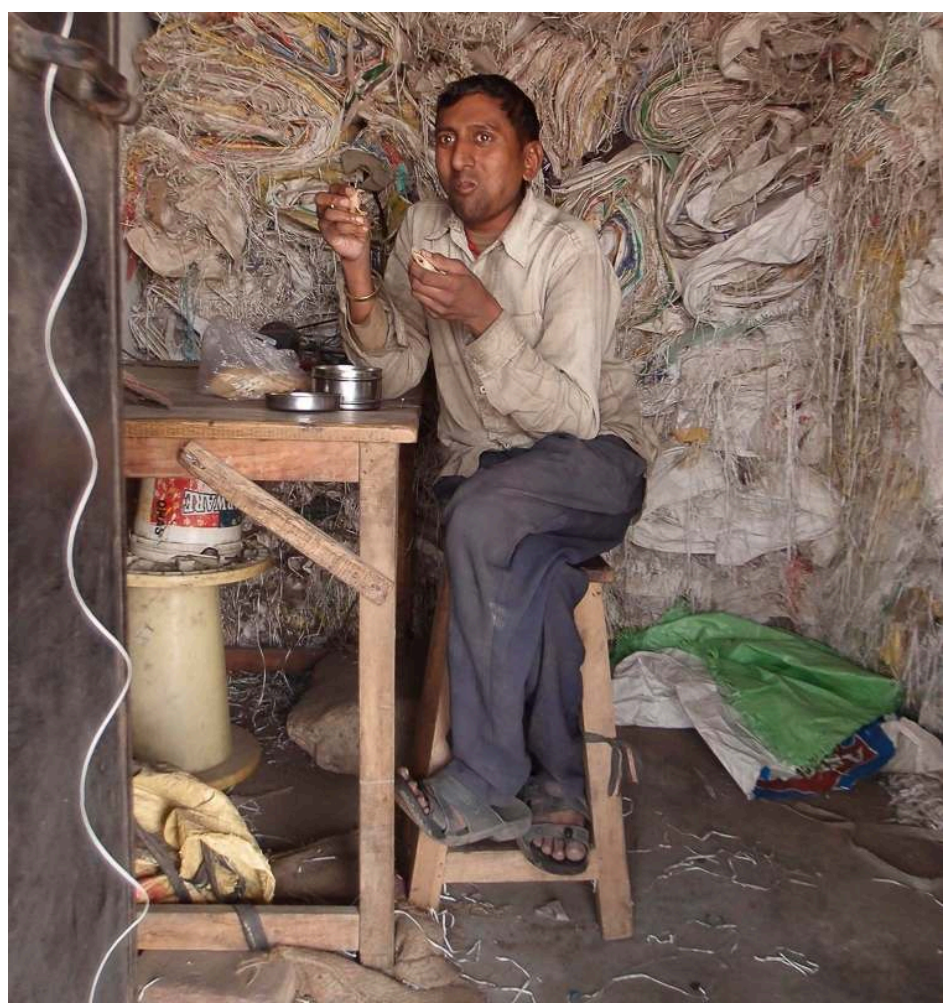

This man is having lunch in his small shop in Nangloi, a working-class neighbourhood in West Delhi, located just opposite a slum of waste pickers. His job consists in collecting and repairing large plastic bags, which are piled up in rolls behind him, and which he then sells on to the inhabitants of the slum. Waste pickers carry these large and thick bags on their backs, filling them up with the waste they pick up around the city, until their bag is packed with large amounts of recyclable materials. Organisations for the protection of waste pickers demand for the authorities to recognise their contribution to the cleaning of public spaces, which would include providing them with more adequate equipment. Until these workers are better integrated, these basic bags will remain an essential tool for the collection of waste and a symbol for the precariousness of waste recovery, a poorly recognised and protected profession.

Nangloi, Delhi, India, January 2016. Photo by R. de Bercegol 


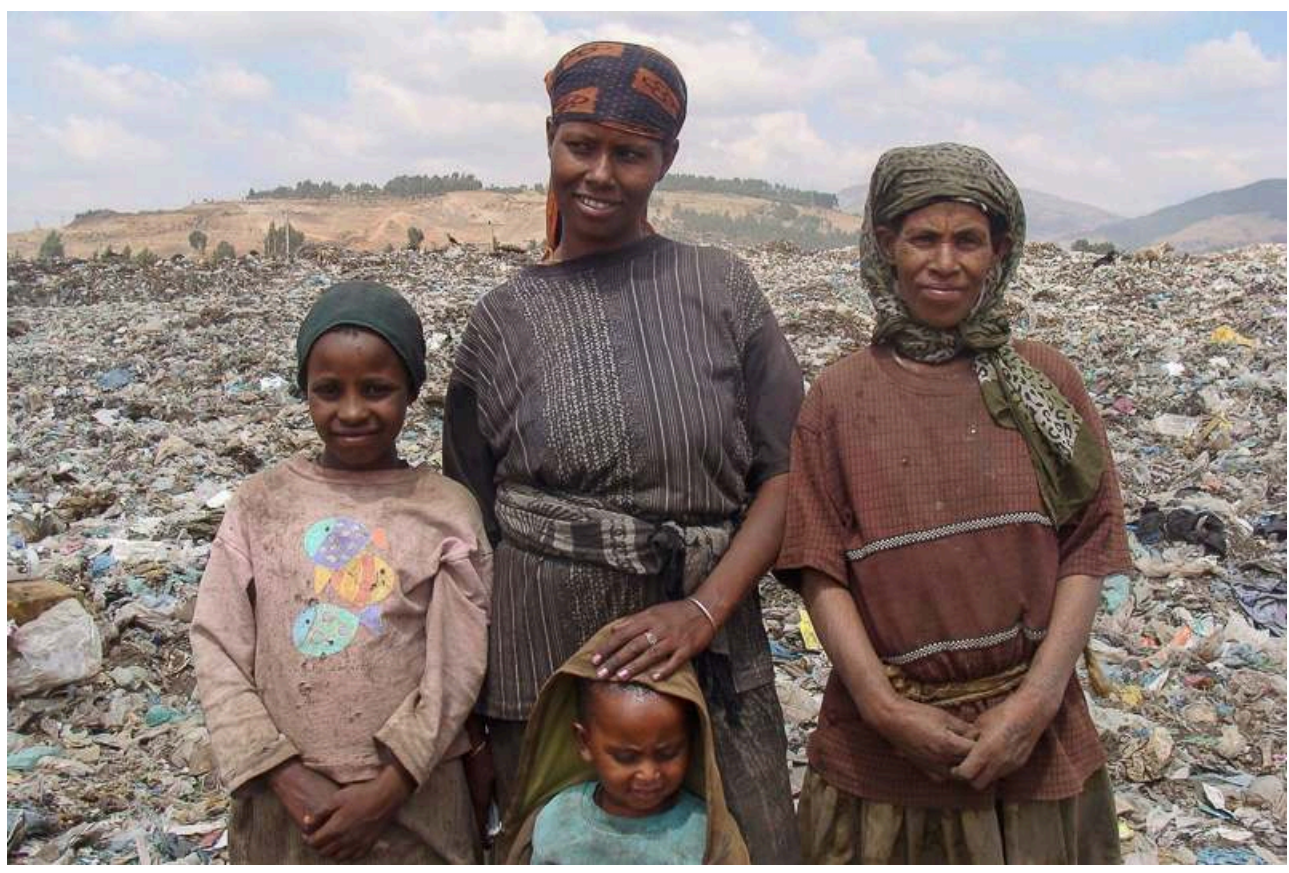

These "waste workers" are family members. They are referred to as Kosheman which in Amharic means "those who work with koshasha", or garbage. They are the hidden face of Ethiopia's capital, which is today undergoing unprecedented changes as illustrated by the slogan: "Clean and Green Addis Ababa". This photograph is the product of a long process of integration among these workers, who were at first suspicious and reluctant to interact with me. After spending several weeks on site, I was gradually able to take notes, to ask people questions and to photograph them at their own request. Some even shared their personal stories. This photograph evokes solidarity, not only among the most disadvantaged but also between generations who work side by side on this landfill site.

Addis Abeba, Éthiopie, May 2009. Photo by A. Pierrat.

\section{Skills: sorting, dismantling, cleaning}

11 The portraits below show men and women in their respective workplaces: peripheral neighborhoods, wholesalers' warehouses in vacant or disaffected areas of central districts, or warehouses used by cooperatives. Collected materials are sorted, in particular when their quality is disparate. They are then weighed by category, in order to adjust the price paid to independent waste pickers according to the wholesalers' rates. Cooperatives seek to add value to the recycling work by adding extra phases to the reclaiming process: they weigh the materials to estimate the quantity of reclaimed materials that enter the warehouse and are transformed before being sold on. In any case, waste pickers are very aware of the value of their load, while buyers are able to evaluate as accurately as possible the quality, quantity and value of the materials.

By this stage, the resources are no longer perceived as waste. They are sorted by type and color, and are ready to be dismantled, cleaned up and compacted, in order to be transformed on the spot or sold on to recycling workshops. The workers pictured here play a crucial role in the operation of the recycling circuit: they act as a link between on the one hand the waste pickers, who work outside the "official" waste management system, and on the other hand, the so-called formal economy, where a material (reclaimed waste) is transformed into an industrial input (Suárez and Schamber 2007). Techniques and tools can vary from one place to the next but everywhere, the skills 
levels are manifest: the workers' dexterity, speed and knowledge of the diverse components all contribute to adding value. Nevertheless, this does not take away from the harshness of these repetitive tasks, involving uncomfortable positions and heavy lifting, as well as very irregular and sometimes very low income (in particular for younger workers).

In terms of the organization of labor, in some contexts (in particular in Latin America), the public authorities accept to manage waste reclaiming activities and integrate them into waste management programs through contracts that regulate public waste collection or the reclaiming of recyclable materials. By joining a cooperative, some of these workers are able to leave their very hard lives and working conditions behind and be integrated into the productive process with social rights, more decent and safer working conditions, and in some cases a minimum wage. In addition, these workers have been able to increase their income thanks to the higher value added to reclaimed materials, which are now processed and assembled by cooperatives instead of being sold on to intermediaries for a very low price. Becoming a member of a cooperative has enabled these workers to gain some rights but also, in some contexts, to engage in public debates on waste management policies. However, while these examples show that some of the waste reclaimers are able to improve their working conditions, many of them still live in highly vulnerable lives, due to their precarious working and living conditions. These workers have no access to social security or job stability; they face many obstacles in organizing themselves freely and are exposed to heavy hierarchical and clientelist relations.

14 The portraits below reflect the undeniable inequality in the positions of these "waste workers", but also the interactions they developed with the researchers over the course of the field research, which are apparent in their gestures, smiles, anecdotes, jokes and proud poses... 
Illustration 8 - Under the bridge

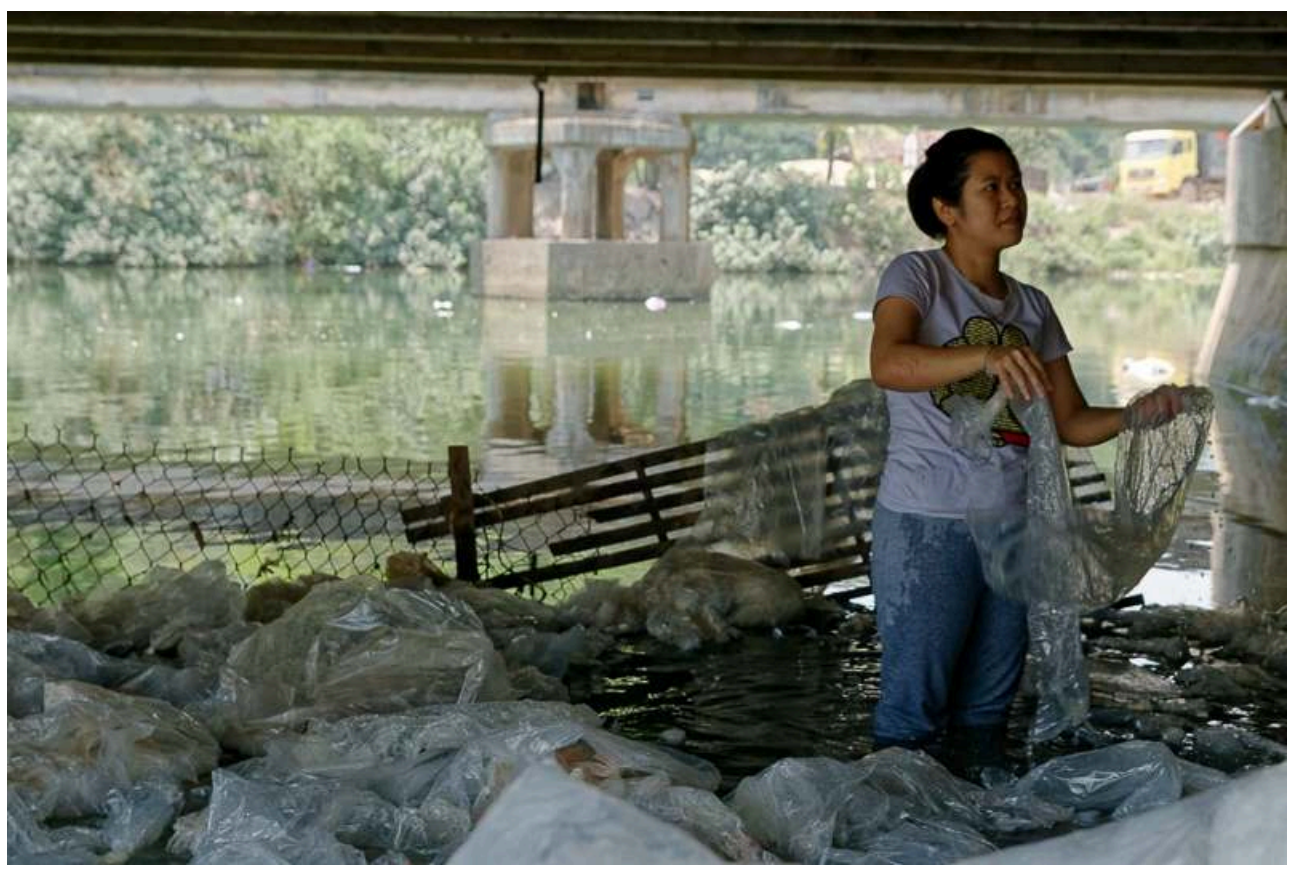

After carrying out several surveys on the issue of waste and plastics pollution in Vietnam, I became accustomed to looking under bridges where waste often accumulated. One day, my eye was caught by plastic bags floating under a busy road near Quy Nhon, a coastal town in the centre of the country. When I walked down under the bridge, I was not expecting to meet a mother and her daughter stooped down, knee-deep in water, busy rinsing clear plastic bags in the water of the river. In order to complement their family's farming income, these women recover plastic bags that once contained seafood, wash them in the river to rid them of their smell and sell them on to one of the plastic recycling factories that recently opened in the region.

Quy Nhon, Binh Dinh, Vietnam, March 2016. Photo by M. Le Meur. 


\section{Illustration 9 - The girl with a pearl earring}

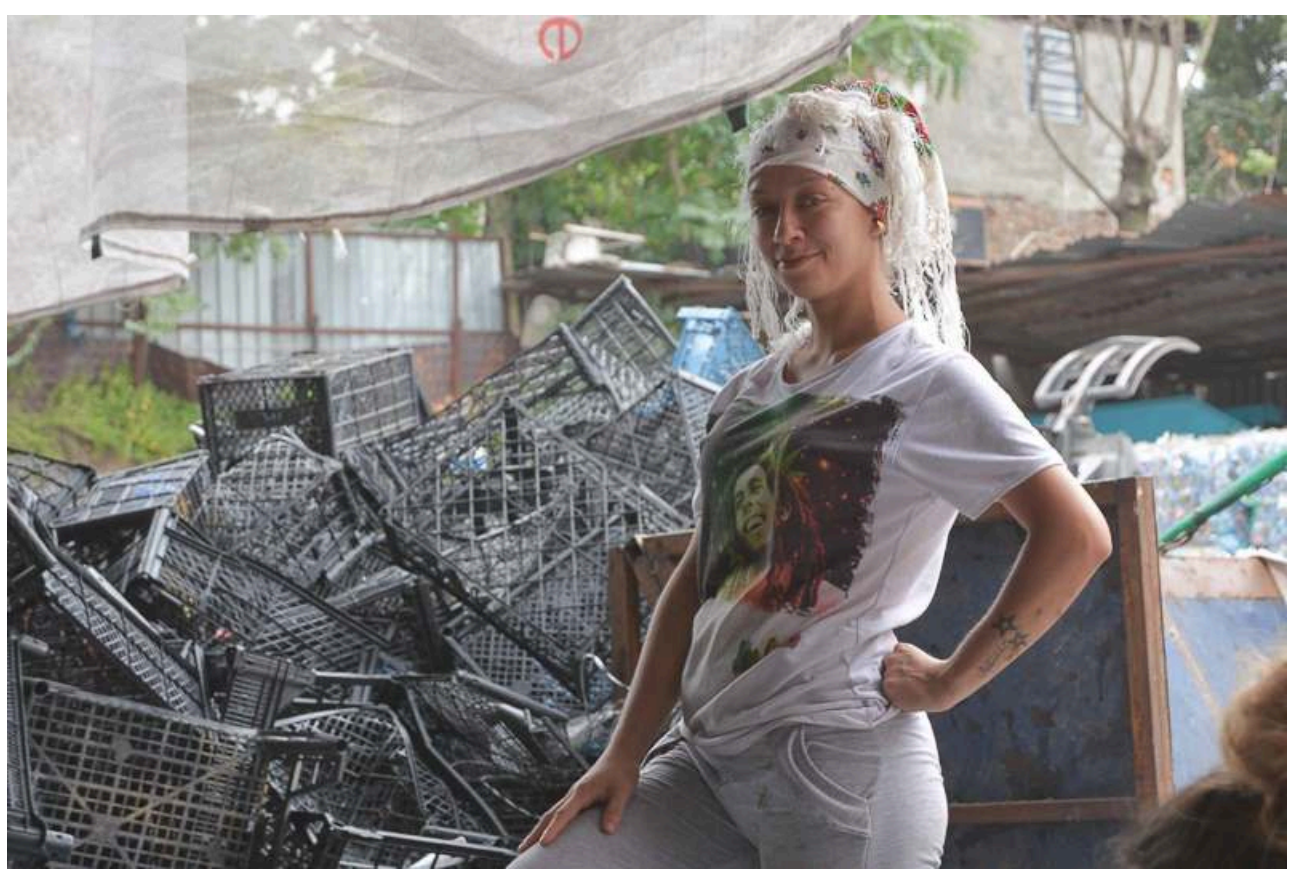

In Istanbul, few female recovery workers operate in the streets. This young Turkish Roma woman is sorting plastic waste, together with other women from her community, in one of the large depots of the Suleymaniye district. She explained that she preferred sorting to reclaiming, which she regarded as dirtier, and that she preferred to work in the safe space of the depot rather than in the street. In spite of their difficult working conditions, these women gave us a warm welcome. After a long interview, they had fun posing for the photographer and showed a visible sense of pride. This young woman chose this pose herself. In retrospect, we found it reminiscent of J. Vermeer's famous painting, "The Girl with a Pearl Earring" (1665).

Istanbul, Turkey, July 2015. Photo by P. Garret, fieldwork in collaboration with B. Florin. 
Illustration 10 - Demanding recognition for "waste workers

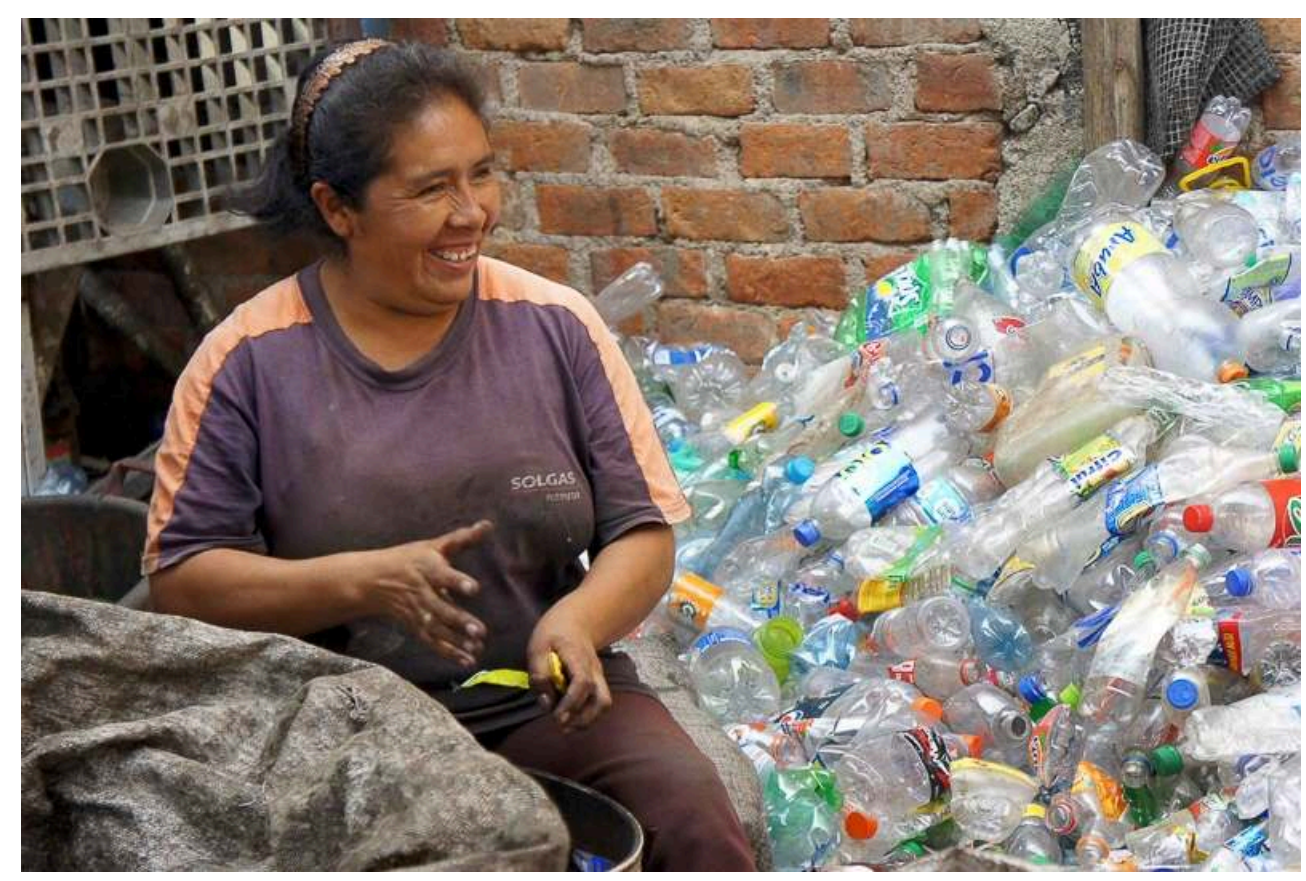

Informal recovery workers collect reclaimable materials by opening garbage bags in the street, while formal workers who work in collaboration with the City Council and NGOs pick up bags of recyclable waste directly from households. This distinction between formal and informal activity derives from the "Recycler's Law", voted in October 2009, which sets a framework for the formalization of this work. Some recovery workers built on this experience to create their own micro-companies, that purchase and transform recyclable waste materials before those are shipped to China or the USA. This photo was taken during a visit of one such pre-processing facility, run by Peruvian NGO Alternativa. The smile on the face of this worker, who is in charge of cleaning bottles, testifies to the gradual recognition achieved by waste work and to people's hopes in the sector's formalization.

Lima, Peru, March 2014. Photo by M. Rateau. 


\section{Illustration 11 - A young bottle cleaner}

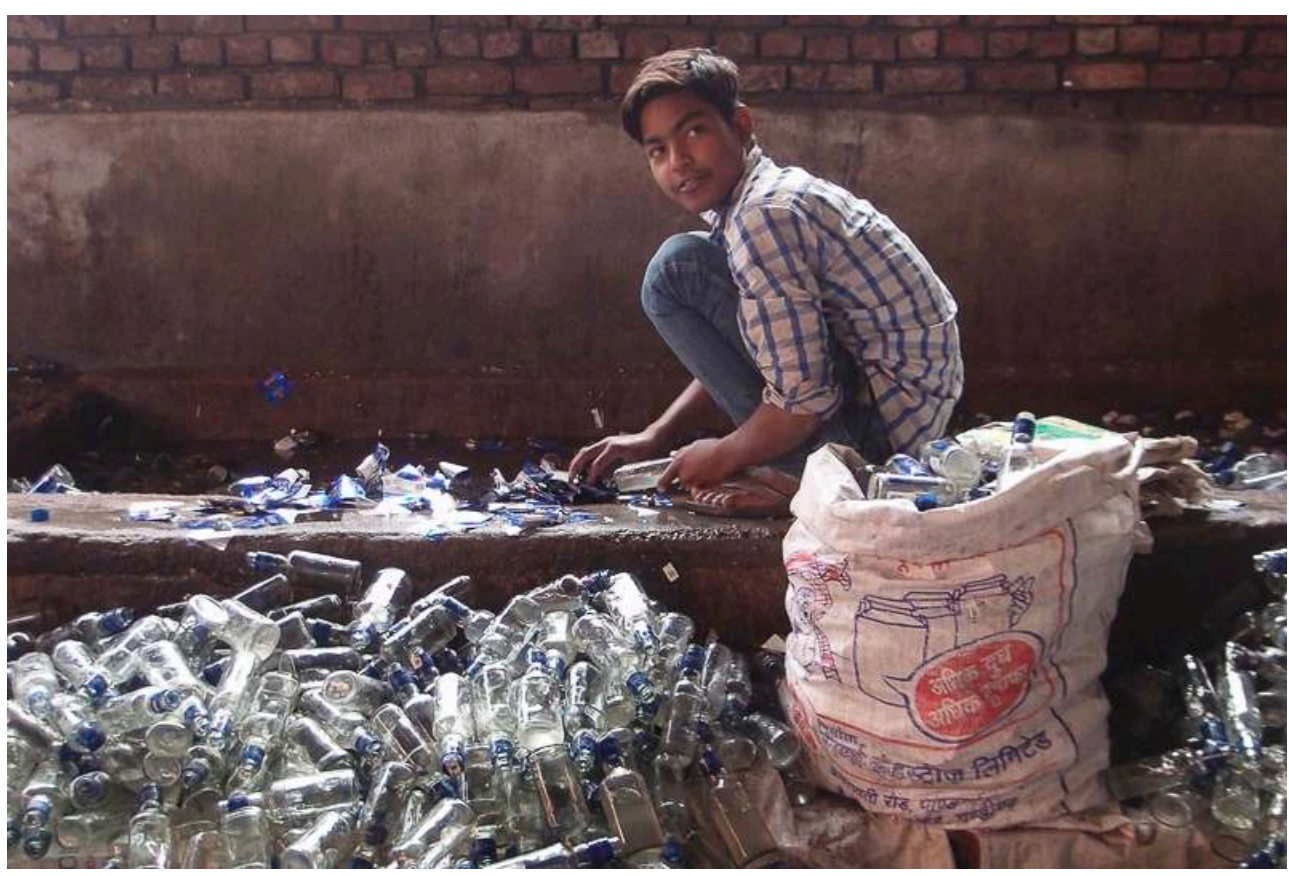

Mohan says that he is fifteen, but he isn't quite sure. He comes from a small village in Uttar Pradesh, a deprived state in Northern India. Mohan found a job in Kanchan Kunj, a district in North Delhi, in a hangar where glass bottles are recycled. Used bottles are delivered by trucks, sorted according to their brand and colour, handwashed and eventually sold to a bottling factory. Mohan is in charge of washing the bottles: he immerses the bottles one by one into a pool of soapy water, gives them a quick scrub and peels off the labels. He is paid by the bottle and did not stop scrubbing while we were chatting. When I returned to the factory a few days later to give him a printed copy of his portrait, I found him in the same position, squatting over his pool, and he barely took the time to wipe his hands before running to his older brother to show him the photograph.

Delhi, India, January 2016. Photo by R. de Bercegol. 
Illustration 12 - The old seamster's skip-house

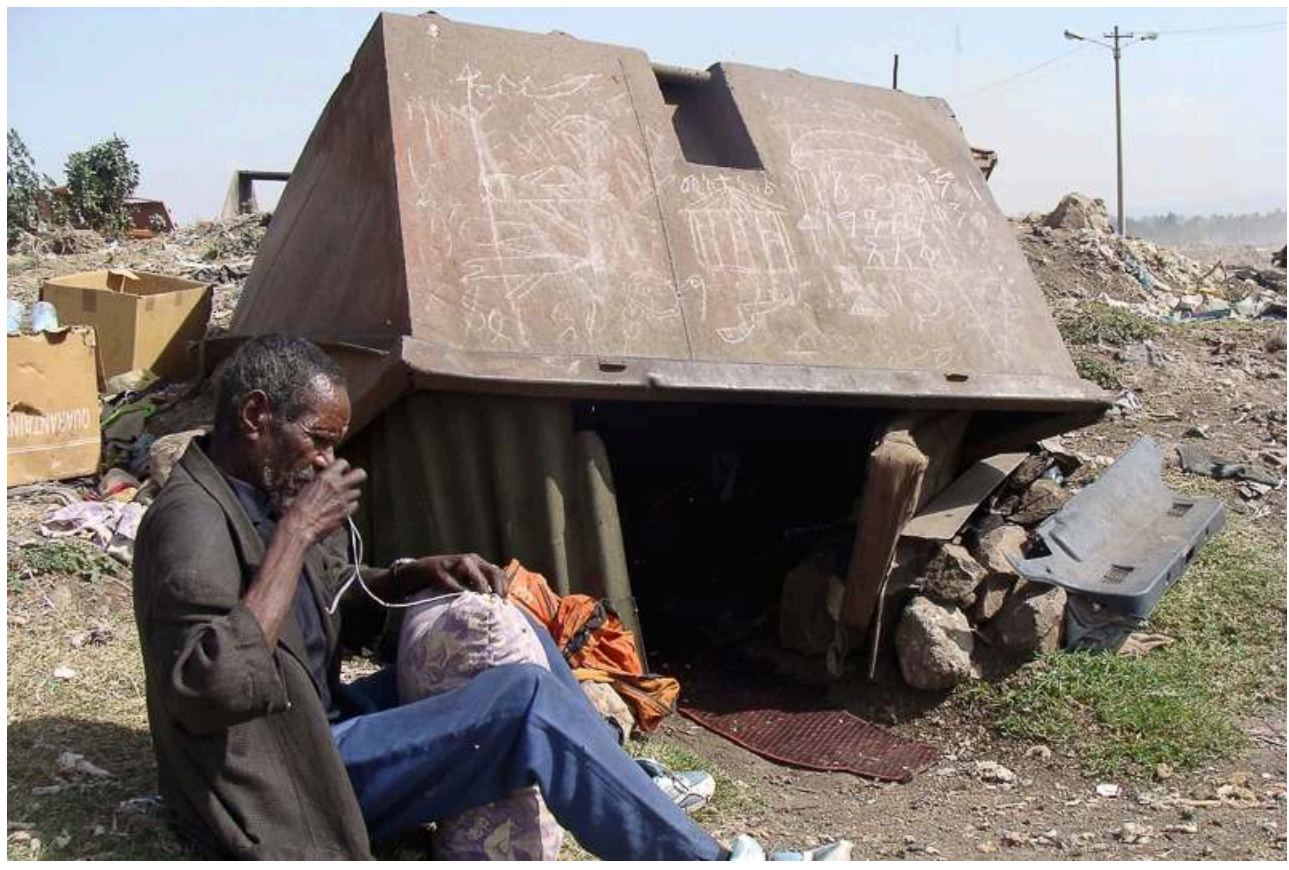

Tesfaye Belaynen, 53, has been sowing pillows in Koshe Repi for 24 years. "I used to live near Dässé, in the Wällo (centre of the country). Then I moved to Addis Abeba during the famine of 1983-1985. Before that, I was a soldier. I couldn't find a job, so I'm living here. Take a look inside... Yes, the färänj (foreigner) woman can take a look too. I am a craftsman." Using reclaimed pieces of fabric that he picks up and stores, or sometimes buys from rag pickers, Tesfaye makes on average two pillows per day. In the background, we can see the old man's home: a skip that has been turned upside down and "converted". By allowing me to take a photograph of his shelter, this recovery worker offers a glimpse into his privacy and vulnerability.

Addis Abeba, Ethiopia, April 2009. Photo by A. Pierrat. 
Illustration 13 - From object to material: dismantling CRT monitors in Nyayo Market

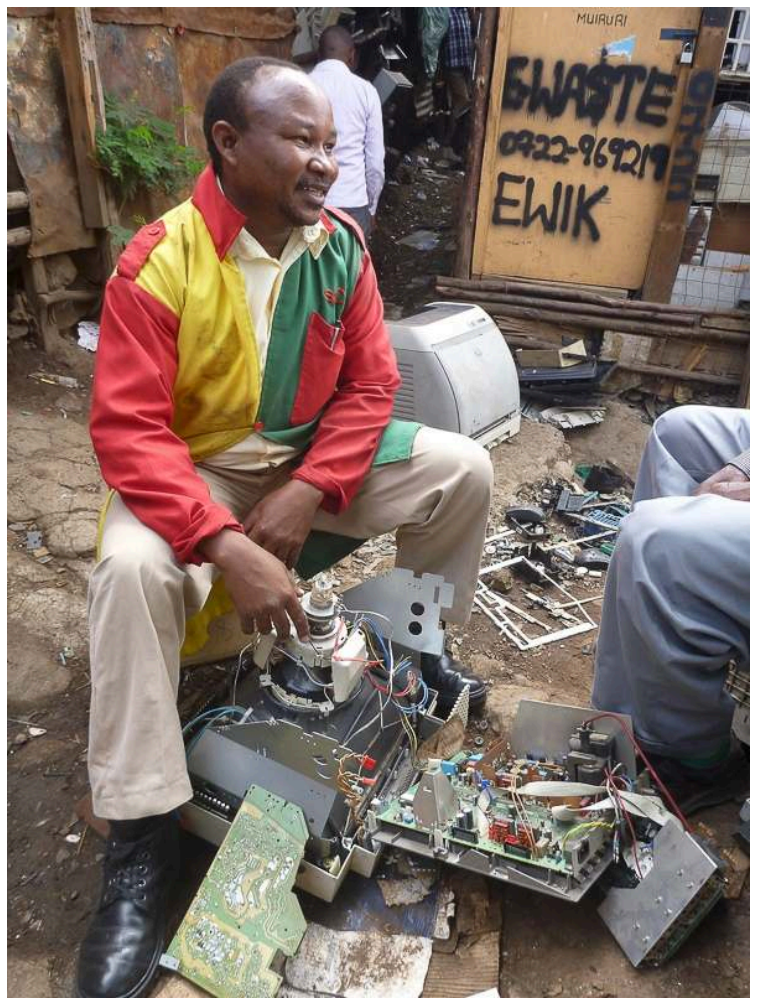

In Nairobi, Nyayo Market is a hotspot for the recycling of electric and electronic devices. Gideon from Western Kenya has a workshop there that specializes in IT equipment. For years, Gideon made a living from reselling second-hand cathode ray tube (CRT) monitors locally or exporting them to Uganda. Now that these devices have gone out of fashion, Gideon dismantles them: their value lies in the copper and precious metals contained in their electronic chips, which are then shipped off to Asia or Europe to be recycled. In the background is the workshop of another fundi (technician in Swahili) who is the president of E-Waste Initiative Kenya (EWIK): a not-for-profit organization that aims to organize their work and achieve more recognition for these workers.

Nairobi, Kenya, February 2017. Photo by R. Reboux. 


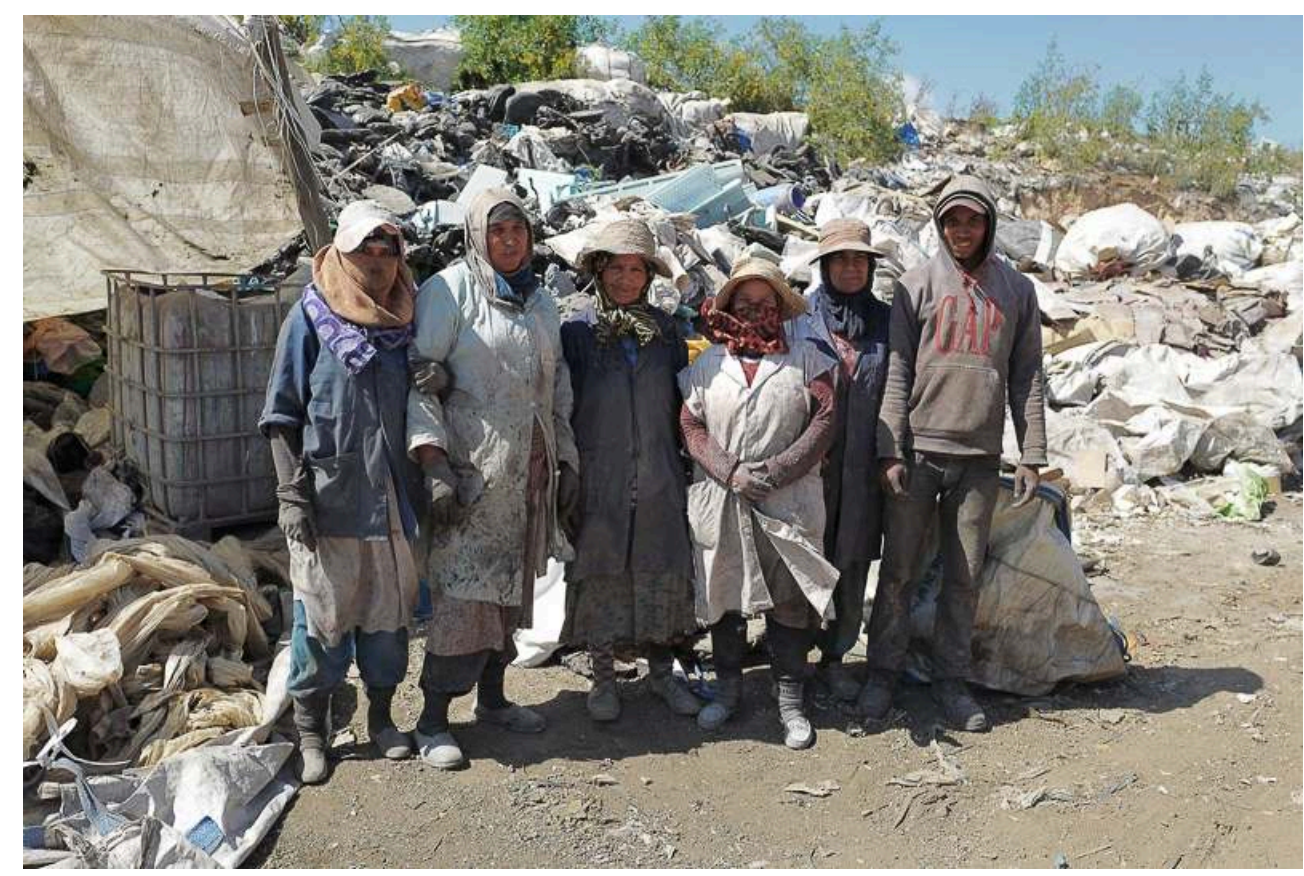

In Casablanca, women are not involved in street collection and are exclusively employed to sort materials brought in by men. Most of them come from rural areas and commute back to their village during harvest season. Their income is low, but it provides a complement for their family and allows them to survive when they live alone. Our interviews and photoshoots with these workers were easy and informative: all were keen for their contribution to urban society, to the recycling industry and to the preservation of the environment to be recognized.

Casablanca, Morocco, May 2016. Photo by P. Garret, fieldwork in collaboration with B. Florin.

\section{Recycling, marketing and circulation}

One of the main challenges for waste reclaimers is to add value to waste collection activities through the transformation and processing of the materials, in order to grow "the value chain of recycling" (Scheinberg and Simson 2015; Jaligot et al. 2016). Waste reclaimers are often at the bottom of the chain: as mentioned above, they collect soiled materials and sell them on at a relatively low price, before other operators then add value to these products. Fundamental conditions to improve or grow waste processing activities and their performance include the ability to invest in equipment, even basic, to have access to water and electricity and to own the land where the warehouses or work facilities are established.

The materials are processed in workshops, where they are transformed into semimanufactured or manufactured products before being marketed. This requires investments for the acquisition of machinery, as well as a increasing levels of professional specialization. There are over a thousand ragpickers' workshops in Cairo. Their recycling equipment - sometimes imitated after foreign prototypes - are often themselves built from recycled materials. The production of plastic consumer products (basins, buckets, clothes hangers, etc.) flourished over the last two decades. Like the industrial estates of Delhi and the "craft villages" of Hanoi that specialize in recycling (IRD-images 2018), Cairo is home to diverse activities with workshops that process 
materials, compress them into bales or pack semi-manufactured products (paper, cardboard, metals, etc.) for the industries of the formal sector.

In other cases, the transformation of reclaimed materials is carried out in the same facilities where they are sorted and cleaned. For instance, to add value to the recycling chain, some Argentinian cooperatives directly grind the plastics and produce granulates, which they then sell on directly to local businesses.

The income of reclaimers and recyclers thus comes from diverse sources: the direct sale of reclaimed materials, the sale of transformed materials (as secondary raw materials or products) and, in some contexts - more particularly in Latin America, where reclaimers have access to political spaces and legal frameworks to develop their work public subsidies from public authorities. For example, in Buenos Aires in the early 2000s, local authorities legalized waste reclaiming and recycling activities: fourteen cooperatives were thus created.

19 The cases studied in this project show the tight connection between informal sector and formal sector activities. This interaction produces a continuum (Cirelli and Florin 2015; Jaglin et al. 2018; Scheimberg et al. 2011; Scheimberg et al. 2016) that is materialized by the circulation of materials, money and workers.

However, the integration of the labor of men and women from the informal sector as well as that of their output only rarely goes along with social rights, labor rights or more equitable pay. The last section of this portfolio focuses on the transformation stage. The portraits give more visibility to these people, who are demanding for their contribution to the economy of waste to be recognized. 
Illustration 15 - El trabajo no es basura / Work is not dirty

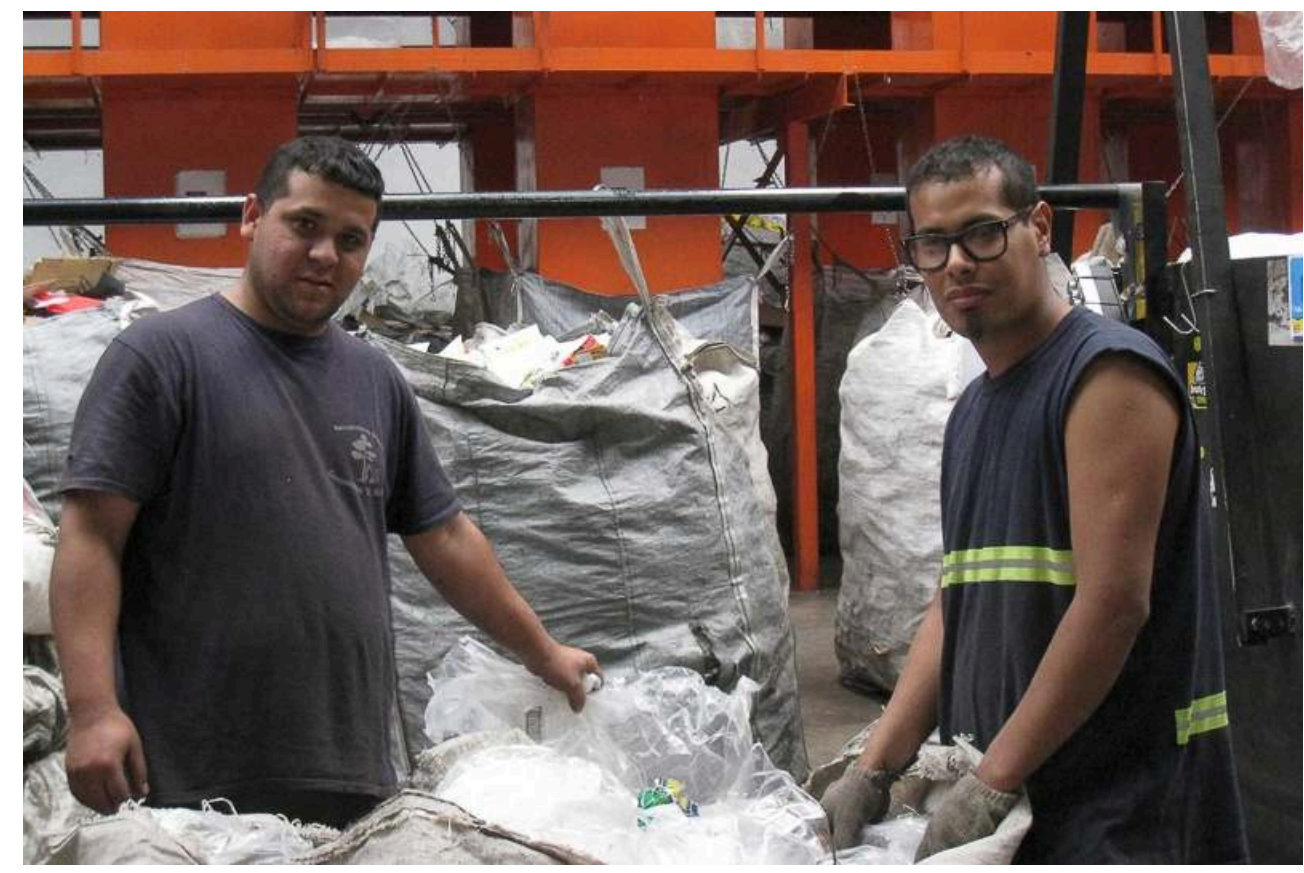

This photo was taken in the premises of the El Álamo cooperative, one of twelve cooperatives that have been integrated to the city of Buenos Aires' environmental services. These two members of the cooperative are sorting plastics. Along with their colleagues, they consider that working with waste "is not dirty" and actually holds a value. The cooperative processes 200 tons of waste per month. Their work, together with that of other associations of recuperadores, generates significant savings for the municipality which would normally pay per ton to have their waste buried. In Argentina, these cooperatives have accomplished significant progress over the past few years: their challenge was not only to improve their members' working conditions and their collection, recycling and marketing capabilities (by bypassing intermediaries), but also to achieve greater visibility, ensuring that their contribution to the urban economy and to the environment is recognized.

Buenos Aires, Argentina, November 2015. Photo by C. Cirelli. 
Illustration 16 - Pak Warjito, a.k.a « the Chief of Ragpickers »

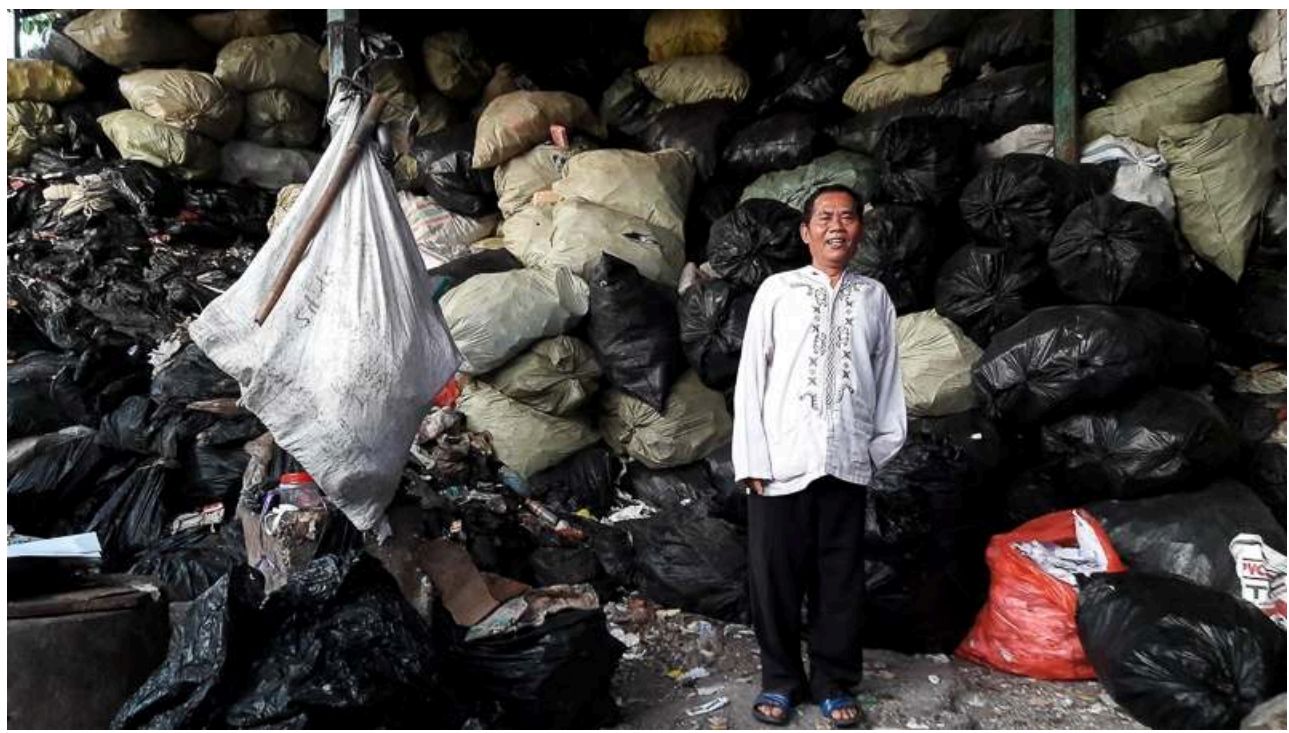

Pak Warjito is a trader, nicknamed « the Chief of Ragpickers ». He once pulled a cart but is now running a team of 20 people collecting waste from shopping malls, hospitals and zoos, and getting paid for it. Pak receives $40 \%$ of the income while his teams get the remaining $60 \%$ as well as the waste materials. His team processes 150 cubic meters of waste per day thanks to their five vans and four pick-up vans. Every day, they haul 4 to 7 tons of residual waste to the landfill site. The remaining materials, mostly glass bottles and paper-plastic, are sold for the equivalent of 800,000 Indonesian rupees per day (under 50 euros) to factories around the city. Since his beginnings, Pak Warjito has earned a considerable wealth: he built himself a beautiful house and has been on pilgrimage to Mecca five times. As for his workers, they are still living in houses on stilts, above mountains of garbage bags swarming with huge rats..

Surabaya, Java, April 2016. Photo by: J. Cavé. 


\section{Illustration 17 - 'Atef's recycling workshop}

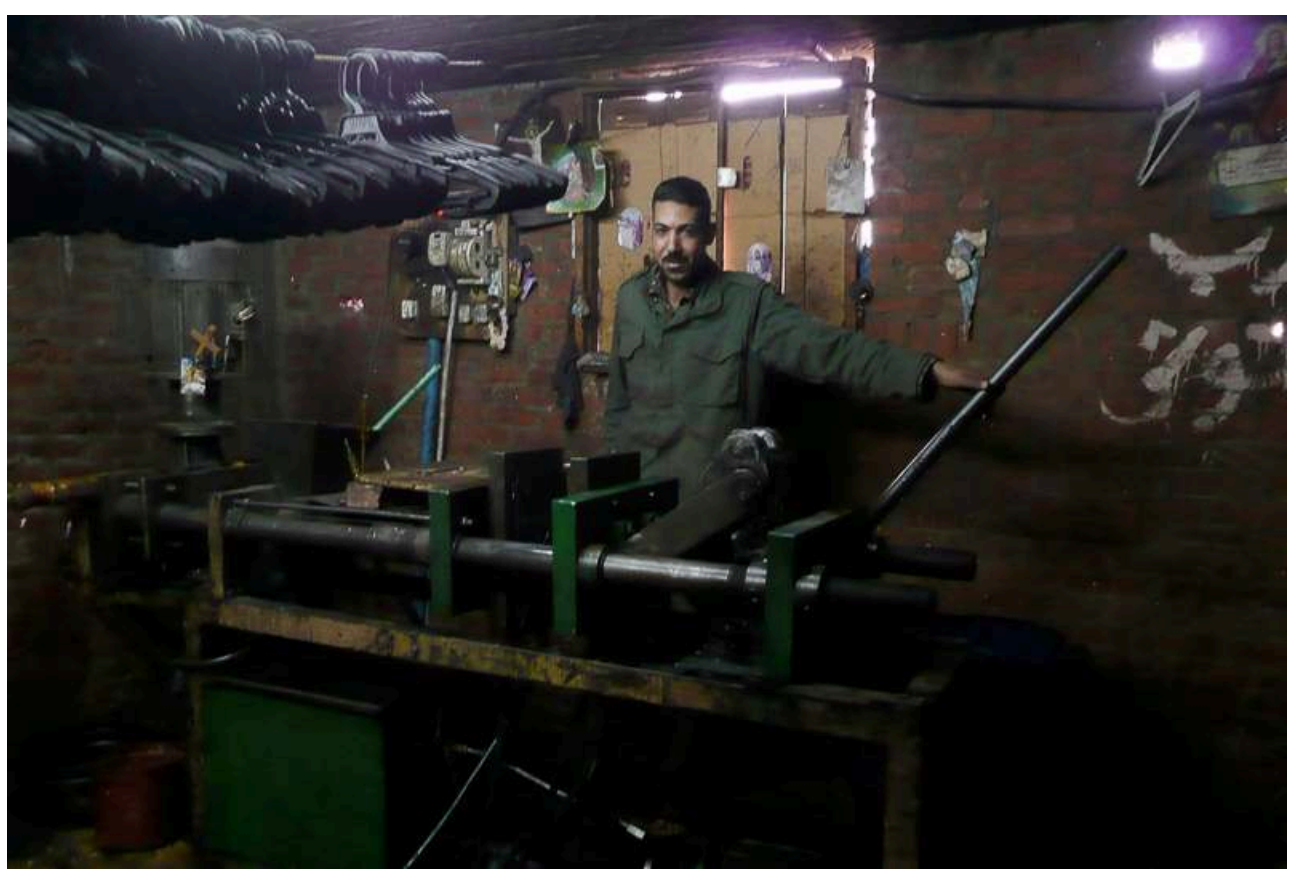

In the ward of Manchiyat Naser in Cairo, 'Atef collects or buys black plastic from local waste pickers to recycle it into clothes hangers, which he then sells on to wholesalers in the city centre. After years spent carrying bags, he became self-employed in 2004 after buying a hanger moulding machine for 800 euros. Since then, he has been able to earn about 80 euros per month. While Cairo rag pickers are seen by many as a symbol of archaism and poverty, 'Asef's story testifies to the fact that social and economic roles can be very diverse and that this community is far from uniform. Skills, initiatives and creativity are essential in ragpickers' activities: far from being the city's "garbagemen", they are first and foremost recyclers and traders. This portrait aims to highlight this aspect of their profession.

Cairo, Egypt, February 2008. Photo by B. Florin. 
Illustration 18 - The millefeuille of the scrap merchant

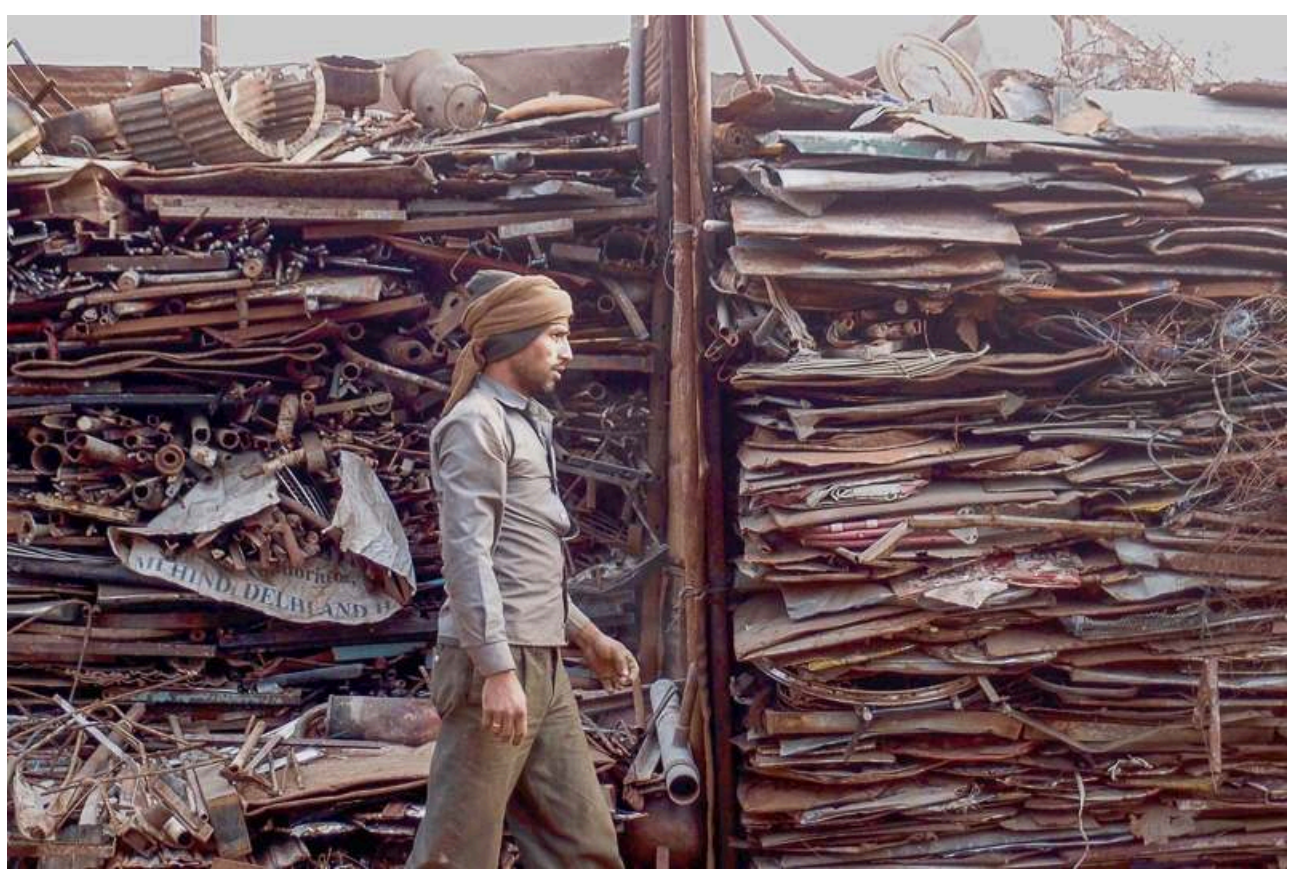

Nasim is walking past a pile of crumpled sheets of metal, piled up according to a precise typology. Scrap metal is sorted according to its composition (iron, cast iron, steel) and separated from other non-ferrous metals (copper, stainless steel, zinc, bronze, aluminium). When we visit the workshop, Nasim is preparing a shipment of iron bound for the foundries of Muzaffarnagar, a city in the North of India, a hundred kilometres from Delhi. Along with other workers, he is carrying heavy panels of iron into the back of the truck, using his bare hands. The thick skin on his hands bears multiple cuts, revealing the stigmata of his strenuous work.

Delhi, India, February 2016. Photo by R. de Bercegol. 
Illustration 19 - The Barakat aluminium foundry

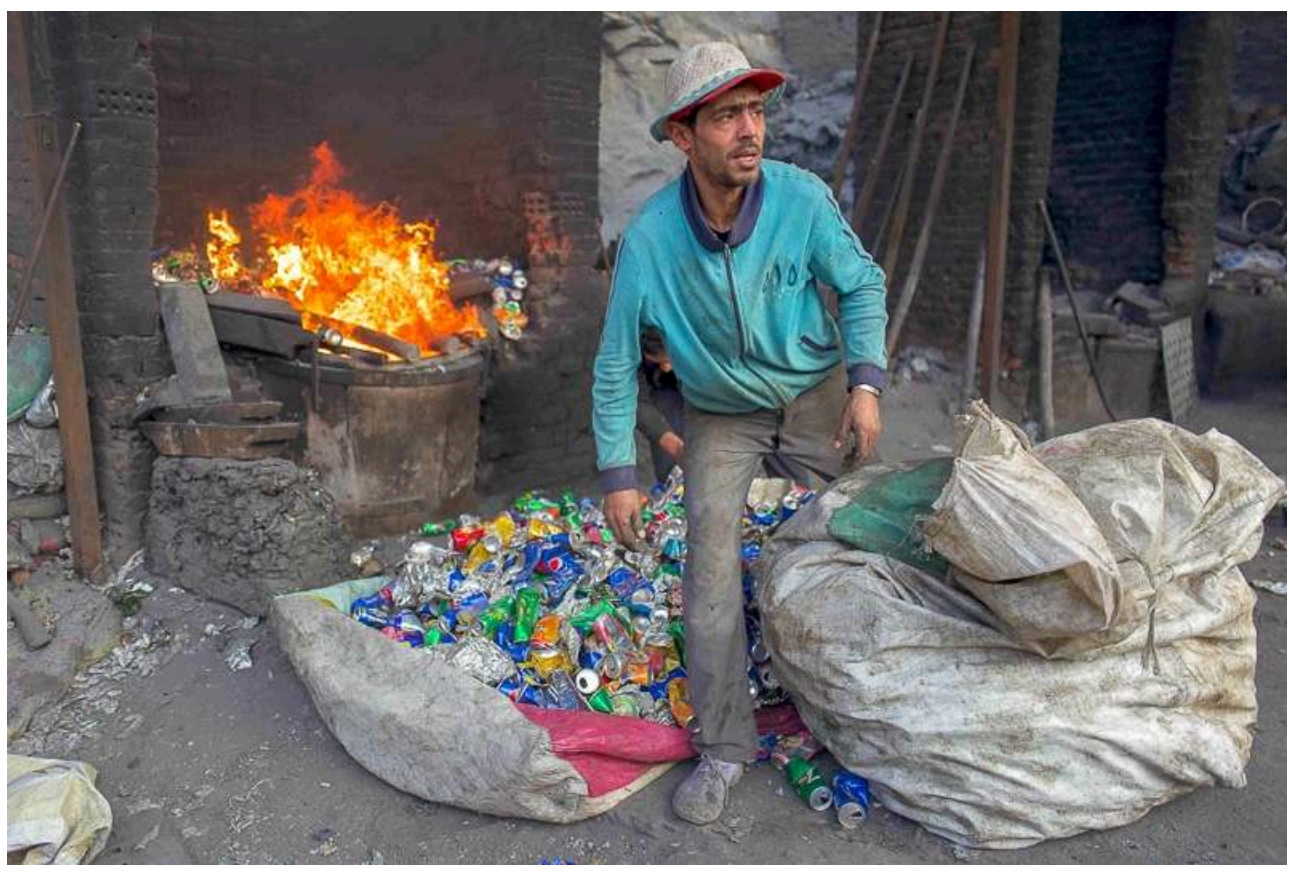

Egyptian zabbâlîn (the word derives from zabbâl, waste) do not just collect and sort waste: they also transform some of the materials they collect, such as aluminium. They use a very simple system to melt the aluminium: a refractory cement crucible with a heating system fuelled by used oil. When the crucible is heated through, the workers fill it with cans: the heat is intense, as shown by the photograph. Liquid aluminium is then poured into bar-shaped moulds and sold on at a good price. Cairo, Egypt, February 2017. Photo by P. Garret, fieldwork in collaboration with B. Florin. 
Illustration 20 - At the car bumper sawmill

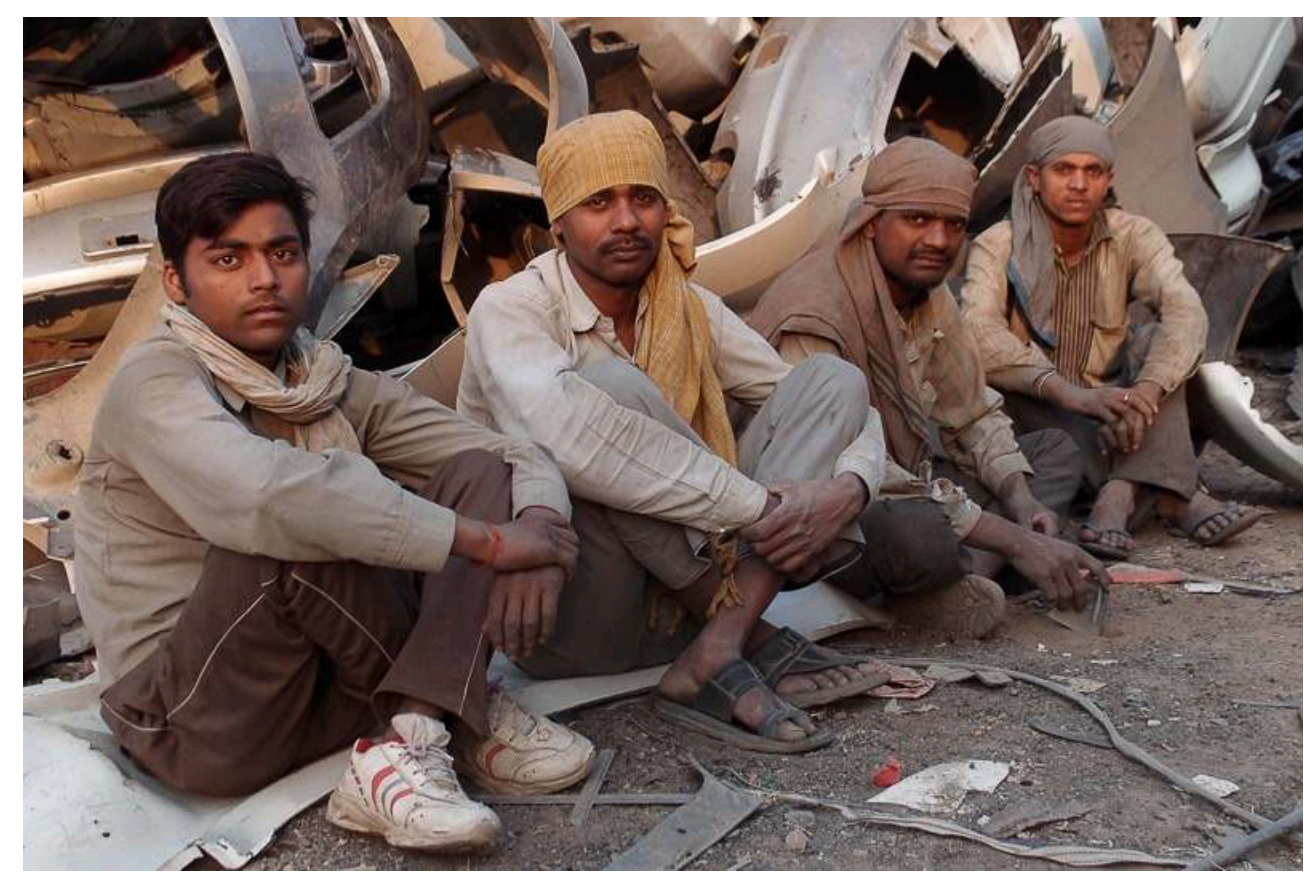

These four workers are employed at a car bumper sawmill in Tikri Kalan within the PVC Market, a market dedicated to the wholesale reselling of plastics where tons of materials are delivered every day before being sorted, processed and sold on. Their job consists in sawing and grinding the car

bumpers that appear in the background - a physically demanding, difficult and dangerous task. Their foreman authorized them to take a quick break so that we could chat for a few moments. Like most workers at the PVC Market, these men belong to the Khatik caste: a community traditionally associated with the impure work of tanneries and relegated to the very bottom of Hindu society. For several decades however, this community has developed new skills: they are now able to tell apart many different types of plastics (polypropylene, polyethylene, polyvinyl chloride, polyurethane, etc.). Some Khatik became rich by exploiting this knowledge (Gill 2010). However, the four men only earn a meagre wage, in the region of 10,000 rupees (the equivalent of under $€ 200$ per month), although they do not dare to complain in front of their employer. The bell rings for the end of the break and soon the workers return to the rumble of the sawmill.

Delhi, India, January 2016. Author: R. de Bercegol. 


\section{Illustration 21 - Mustapha, owner of a gelssa}

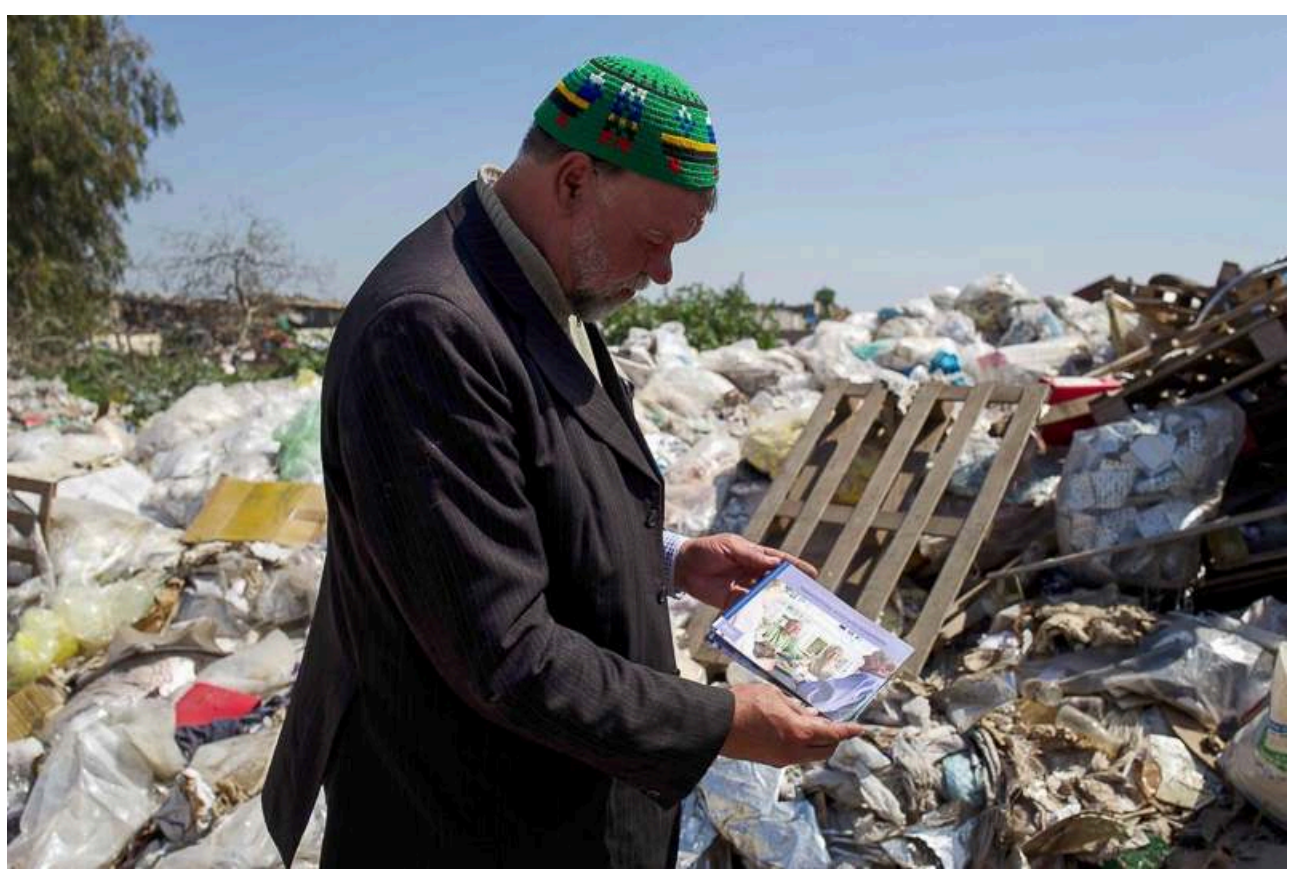

Mustapha is the owner of a gelssa (the word derives from the verb gels, "to sit down" in Moroccan dialect) in the Lahraouine district of Casablanca. Gelssas are fenced enclosures of varying sizes where materials brought in by street waste pickers are sorted and transformed. Mustapha attempted to create an "Association for the defense of recycled material retailers" to advocate for their recognition by public authorities. "The aim was to help people and organize our activity through an association to gain access to rights and healthcare. This profession is poorly recognized, but people are really keen to defend themselves." Although the association was not authorized by the authorities, Mustapha continues his struggle as much as he can. "We are contributing to the country's economy. If it were not for us, these materials wouldn't get recycled, they would just have to be burnt."

Casablanca, Maroc, April 2017. Author: P. Garret. 
Illustration 22 - Moolchand

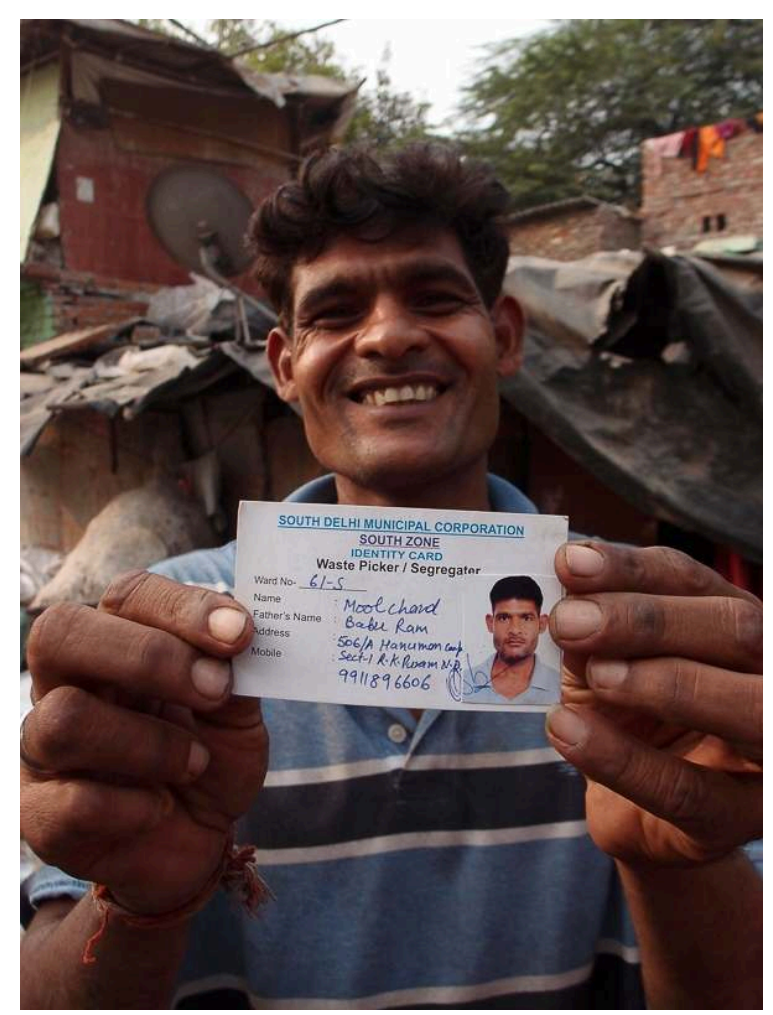

Moolchand is a waste picker from Uttaranchal, but he has been working in South Delhi for about fifteen years. I followed him on various occasions, and regularly visit him during my missions in India. On that day, Moolchand was happy to show me the waste picker ID card he had just received, which provided him with a relative protection during police checks. However, this does not mean that his job is now formalized: Moolchand is not really integrated to the city council services, he remains selfemployed, receives no equipment from the municipality and is not entitled to any social security or salary, although he contributes to cleaning the streets of his local area. Moolchand's situation is mirrored by the very basic shelter that can be glimpsed behind him: he remains a vulnerable worker, in need of more recognition.

Delhi, India, January 2016. Photo by R. de Bercegol.

\section{Conclusion}

While for years, waste was kept out of sight, perceived as contaminated and assigned a negative symbolic value associated with filth and chaos, it is today the object of collection and reclaiming processes, in order to extract valuable materials before it is discarded. Broken down into various components - plastics, metals, paper, etc. - waste is a resource that can create value. This potential is all the more crucial that the shortage of energy and mineral resources is now creating a growing demand for transformed raw materials and recycled products.

The recognition of the role of the informal recycling sectors appears essential to improve its efficiency and reward the work carried out by reclaiming workers. Improving collection and sorting conditions could increase the volume of recycled materials: this would reduce the costs associated with the transportation and final elimination of waste, as well as improving people's working conditions and supporting the urban economy. Waste is a primary resource for many people who directly depend upon it and are involved at diverse levels, from collection to sorting through to 
transformation. This reclaiming economy provides a basic income for hundreds of thousands of families, in turn sustaining the formal industries that produce consumer goods.

The sector's integration will not happen unless the tasks accomplished by waste reclaimers are recognized as "real work" that contributes to society like other professions, as highlighted by many of the people interviewed for this project ${ }^{5}$. While this activity is still considered illegal in many countries, waste workers regard the economic, environmental and social value of reclaiming as beneficial to society, and therefore as a worthy activity that helps improve the quality of life of the workers and their families, but also that of all urban people. Legitimizing this activity would alleviate the negative symbolic load associated with these workers' contact with filth, which they often interiorize as shame. These workers' claims for more recognition stem from the feeling of not being respected or recognized (Honneth 2000). In addition, waste pickers suffer from the legal penalization of their activity, and from their negative working conditions that can create social relations of subordination, domination and exploitation.

It is urgent to move beyond this sector's miserabilist image: its conditions are of course imperfect in many ways, but abuses are made worse by the sector's relegation to informality. Integrating these workers to waste management policies could help ensure the gradual implementation of social and environmental standards. This is what the exhibition La Mise en image du rebut aims to achieve, on a modest scale, where this portfolio is complemented by additional field studies and photographs. By presenting it to diverse audiences (researchers, students, waste sector professionals, schools, general public), in diverse formats (events, conferences, seminars, round tables) and in different venues ${ }^{6}$, we aim to raise awareness and use the medium of image to make "spectators" reflect on our relation to waste, thus changing perceptions of these workers.

\section{BIBLIOGRAPHY}

Chokhandre P., Singh S., Kashyap G. C., 2017. Prevalence, predictors and economic burden of morbidities among waste-pickers of Mumbai, India: a cross-sectional study. Journal of occupational medicine and toxicology[En ligne], vol. 12. doi : 10.1186/s12995-017-0176-3

Cirelli C., Florin B., (dir.), 2015. Sociétés urbaines et déchet. Éclairages internationaux, Presse Universitaire de Tours, Tours.

Corteel D., Le Lay S. (dir.), 2011, Les travailleurs des déchets. Toulouse, Érès, 336 p.

Dagognet F., 2009. Éloge du déchet. In Beaune J.-C. (dir.), Le déchet, le rebut, le rien. Seyssel, Champ Vallon, p. 200-209

Friedmann D., 2010. Sociologie filmique, sociologie visuelle et écrit. La sociologie par l'image, Revue de l'Institut de Sociologie, $n^{\circ} 11$. 
Gill K. (dir.), 2012. Of Poverty and Plastic: Scavenging and Scrap Trading Entrepreneurs in India's Urban Informal Economy. New Delhi, Oxford University Press, 287 p.

Gunthert A. et al., 2007. La Fabrique des images contemporaines. Paris, Editions du Cercle d'art, 192 p. Honneth A., 2000 [ $1^{\text {ère }}$ ed. all. : 1992]. La lutte pour la reconnaissance. Paris, Les Éditions du Cerf, $232 \mathrm{p}$.

Ird-images, 2018. Recyclage au Vietnam, Dồng nát \& villages des métiers, film institutionnel. Réalisation : Boré J.M. - IRD IMAGES, 10’03min.

Jaligot R., Wilson D.C., Cheeseman C., Shaker B., 2016. Applying value chain analysis to informal sector recycling: a case study of Zabaleen. Resources, Conservation and Recycling, $\mathrm{n}^{\circ} 114$, p. 80-91.

Jaglin S., Debout L., Salenson I., 2018. Du rebut à la ressource. Valorisation des déchets dans les villes du sud. Paris, Agence Française du Développement, 296 p. https://www.afd.fr/fr/du-rebut-laressource

Jeanjean A., 2006. Basses Euvres : une ethnologie du travail dans les égouts. Paris, Éd. du CTHS, 279 p. Lhuilier D, Cochin Y., 1999. Des déchets et des hommes. Paris, Desclée de Brouwer, 184 p.

Louveau de la Guigneraye C., Arlaud J., 2007. De la photo au film : écritures numériques. Ethnologie française, vol. 37, p. 101-106.

Perelman M.D., 2007. Rebusque o trabajo? Un análisis a partir de las transformaciones del cirujeo en la Ciudad de Buenos Aires. In Suárez F., Schamber P. (coord.), Recicloscopio. Miradas sobre recuperadores urbanos de residuos en América Latina. Buenos Aires, Universidad Nacional General Sarmiento, Universidad Nacional de Lanús, Prometeo Libros.

Scheinberg A., Spies S., Simpson M.H., et al., 2011. Assessing urban recycling in low- and middle income countries: Building on modernized mixtures. Habitat International, n 35, p. 188-198.

Scheinberg A., Simpson M., 2015. A tale of five cities: using recycling frameworks to analyse inclusive recycling performances. Waste Management Resources, $n^{\circ} 33$, p. 975-985.

Scheinberg A., Nesic J., Savain R.A., et al., 2016. From collision to collaboration: Integrating informal recyclers and re-use operators in Europe, a review. Waste Management \& Research, vol. 34, $\mathrm{n}^{\circ}$ 9, p. 820-839.

Sontag S., 1977. On Photography. Penguin Books, London, 224 p.

Suárez F., Schamber P., (coord.), 2007. Recicloscopio. Miradas sobre recuperadores urbanos de residuos en América Latina. Universidad Nacional General Sarmiento, Universidad Nacional de Lanús, Prometeo Libros, Buenos Aires.

\section{NOTES}

1. Literally in English "Images of waste: materials, bodies and practices around waste", the exhibition has been renamed according to the local context when presented in front of an English speaking audience (see footnote $n^{\circ} 6$ ) https://sud.hypotheses.org/ 1940

2. The project Sociétés Urbaines et Déchets (SUD) is led by the eponymous research team founded in 2009 by Claudia Cielli and Bénédicte Florin, respectively members of the CoSTand EEMAM teams of research group UMR 7324 CITERES (National Center for Scientific Research, University of Tours). Through a cross-disciplinary and international approach, the members of 
SUD aim to capture the reconfigurations and tensions at play in urban waste management. After several research seminars, meetings and joint events, SUD gathered momentum and now brings together over forty researchers and professionals with an interest in waste. The activities of the SUD project are also documented online at https://sud.hypotheses.org

3. For editorial reasons, this methodological work (information sheet for each photograph) is not presented in this portfolio.

4. The question of informal waste work is often only studied from the perspective of "Southern countries", although every day we see people in French cities who make a living from collecting and reselling waste. The article "Faire la ferraille en banlieue parisienne" ("Collecting scrap metal in the peripheries of Paris") published in this issue of EchoGéo provides multiple examples of this work (Florin and Garret 2019).

5. Studies on the many people who became waste pickers after losing their job testify to the importance of this demand (Perelman 2007).

6. Local variants of the exhibition have been developed according to the context: for instance in Delhi during the City of Waste event (organized in February-October 2018 by Rémi de Bercegol, Christine Ithurbide and François Grosjean at the Indian Habitat Centre, Mandi House Metro station and Jamia Millia Islamia University), the portfolio was complemented by field photographs shot in India. The SUD network is happy to collaborate with any institution who might be interested in hosting the exhibition, and welcomes proposals for research collaborations. Contacts: https://sud.hypotheses.org/credits

\section{AUTHORS}

\section{CLAUDIA CIRELLI}

Claudia Cirelli, claudia.cirelli@univ-tours.fr,is an Associate Researcher at Université de Tours (Research Unit : UMR CITERES). Recent publications include :

- Cirelli C., Rosa É., 2018. Scavenging: Between precariousness, marginality and access to the city. The case of Roma people in Turin and Marseille. Environment \& Planning A, vol. 50, $\mathrm{n}^{\circ} 7$, p. 1407-1424.

- Cirelli C. et al., 2017. "L'incinérateur est trop près, la poubelle trop loin" : gérer les déchets en régime de proximité. Flux, $\mathrm{n}^{\circ}$ 109-110, p. 61-72.

- Cirelli C., Florin B., (dir.), 2015. Sociétés urbaines et déchets. Éclairages internationaux. Tours, Presse Universitaire de Tours, $452 \mathrm{p}$.

\section{BÉNÉDICTE FLORIN}

Bénédicte Florin,benedicte.florin@univ-tours.fr, is a Senior Lecturer at Université de Tours (Research Unit : UMR CITERES, Arab and Muslim World (EMAM)). Recent publications include : - Florin B., 2018. The Rag Pickers of Cairo: The Dregs of the City or "Garbage Businessmen"? Ethnologie française, $\mathrm{n}^{\circ} 153$, p. 487-498.

- Florin B., 2016. De l'indignité à l'indignation : petites luttes, résistances quotidiennes et tentatives de mobilisation des récupérateurs de déchets à Istanbul. Cultures \& conflits [En ligne], n 101 , p. 99-120. http://journals.openedition.org/conflits/19184

- Allix É., Florin B., 2016. Indésirables dans la ville, utiles dans l'ordure. Les récupérateurs de 
déchets au Maroc. Géographie et culture [En ligne], n 96, p. 23-45. http://

journals.openedition.org/gc/4434

\section{RÉMI DE BERCEGOL}

Rémi de Bercegol, remi.debercegol@cnrs.fr, is a Research Fellow at the National Center for Scientific Research (CNRS) and a member of the Research Unit UMR PRODIG (Paris). He coorganized the exhibition The City of Waste in Delhi (2018) and Pondicherry (2020), from which the photographs below have been taken. Recent publications include :

- de Bercegol R., 2019 [1ère ed. 2010]. Small Towns and Decentralisation in India. Rawat Publications [1ère ed. Springer], $246 \mathrm{p}$.

- de Bercegol R., Gowda S., 2018. Waste and Energy Nexus: Rethinking the modernisation of waste services in Delhi. Urban Studies, Special Issue on 'Urban Nexus', June 2018.

- de Bercegol R., 2018. Les enjeux de la valorisation des déchets à Delhi. In Jaglin S, Debout L., Salenson I., (dir.), Du rebut à la ressource. Valorisation des déchets dans les villes du sud. Paris, AFD, p. 31-49. 